\title{
CORPORATE GOVERNANCE ATTRIBUTES AND TAX PLANNING OF LISTED PHARMACEUTICAL COMPANIES IN NIGERIA
}

\author{
Appah Ebimobowei (Ph.D, FCA) \\ Isaac Jasper Boro College of Education, Sagbama, Bayelsa State, Nigeria \\ +2348037419409; appahebimobowei@yahoo.com
}

\begin{abstract}
Cite this article:
Appah Ebimobowei (2022),

Corporate Governance Attributes and Tax Planning of Listed Pharmaceutical Companies in Nigeria. British Journal of Management and Marketing Studies 5(1), 1-38. DOI: 10.52589/BJMMSACK6RKJK
\end{abstract}

\section{Manuscript History \\ Received: 3 Jan 2022 \\ Accepted: 25 Jan 2022 \\ Published: 17 Feb 2022}

Copyright $\odot 2022$ The Author(s). This is an Open Access article distributed under the terms of Creative Commons AttributionNonCommercial-NoDerivatives 4.0 International (CC BY-NC-ND 4.0 ), which permits anyone to share, use, reproduce and redistribute in any medium, provided the original author and source are credited.
ABSTRACT: Corporate governance is a means in which businesses are fairly, efficiently, effectively and transparently managed in order to achieve corporate goals through better practices and structures. This study investigates the effects of corporate governance characteristics on tax planning of listed pharmaceutical firms in Nigeria from 2015 to 2020. The study used ex post facto correlational research design and a population of eleven (11) pharmaceutical firms made up the population of the study. The data was collected from the published financial statements of the sampled firms as at 31 December, 2020. The secondary data from the annual reports were analysed using univariate, bivariate and multivariate analysis. The multiple regression results disclosed that board size and board financial expertise positively and insignificantly impact tax savings; board compensation and board meetings negatively and insignificantly affects tax savings while gender diversity negatively and insignificantly influences tax savings. Board financial expertise positively and significantly influences book-tax difference while board size, gender diversity, board compensation and board meetings negatively and insignificantly impact book tax difference. The study concluded that corporate governance characteristics influences tax planning of listed firms in Nigeria and hence recommended amongst others that shareholders must preserve a structure to guarantee that the board is given financial incentives for effective tax planning that will assist to solve the agency problem where management exploits shareholders through tax planning practices.

KEYWORDS: Corporate Governance, Tax Planning, Board Size, Tax Savings, Book Tax Difference 


\section{INTRODUCTION}

Corporate governance is a very important topic in contemporary accounting and management research. According to Chytis, et al (2019), corporate governance is all about the relationship between the owners and managers in directing and controlling companies as separate entities. Onyema and Major (2021), Hasibuan and Khomsiyah (2019); Ogbeide and Obaretin (2018) state that corporate governance is a system of directing and controlling corporate entities, be they in the private sector, public sector or be they financial institutions to fulfill long - term strategic goals, taking care of the welfare of their employees and the local community, maintaining harmonious relations with their suppliers and customers and work in compliance with the legal framework that exists in the country and use such processes of production that generate minimum externalities of the negative kind of the nation as a whole (Yuniarsih, 2018; Waluyo, 2017). It provides the mechanisms, processes and structures by which management ensures that resources are effectively and efficiently managed to achieve desired results by the owners (Salawu \& Adedeji, 2017; Uchendu et al, 2016). Worlu (2018) maintain that corporate governance encompasses the efficient and effective management of the resources of a firm within the ambit of regulatory, compliance and risk management principles.

Waluyo (2017) suggested that the major aim of good corporate governance is generally associated with the accountability, responsibility and mechanism of the company to ensure a good attitude of the firm to protect the requirements of shareholders' including the payment of corporate and other taxes (Omesi \& Appah, 2021). The major aim of good corporate governance is to ensure the efficient use of resources to reduce corporate fraud and mismanagement with the purpose of maximising shareholders wealth and aligning the conflicting interests of all stakeholders (Yimbila, 2017). Hasibuan and Khomsiyah (2019) noted that the good corporation governance reduces agency problems and improve corporate performance. The study of Irawan and Farahmita (2013) revealed that good corporate governance affects the tax aggressiveness of companies. Murni, et al (2016) made the submission that good corporate governance inspires confidence to investors; liberalization of financial markets; improvement of the basis for the establishment of new corporate value system.

Taxes are a major source of revenue to every given nation on planet earth. According to Omesi and Appah (2020), taxes are the main source of revenue to government all over the world. Chukwudi et al, (2020), state that taxes are one of the main instruments of fiscal policy employed by government to regulate the economy of any given nation. Omesi and Appah (2020) further stated that tax is a compulsory contribution made by members of any given society to the state subject to the jurisdiction of the government for the purpose of generating revenue to facilitate economic growth, economic stabilization, income redistribution, promoting fairness and equity, fiscal responsibility and accountability, as well as for the provision of national goods and services. Mais and Patmininingih (2017), state that taxpayers are expected to contribute to the growth and development of any given economy. However, taxpayers view the payment of taxes as burden hence minimizes the burden of corporate income tax by using the loophole of the various tax provisions. The minimization of tax burden can be achieved through tax planning. Chukwudi, et al (2020) argued that tax planning is any activity taken by a firm in compliance with the relevant tax laws that can explicitly minimize corporate tax liability. It entails taking advantage of the dynamism and loopholes existing in tax legislations to minimize tax burden. Similarly, Kiabel and Akenbor 
(2014) argue that the minimization of tax liability can be achieved through proper tax planning by transferring value from the government to corporations. Tax planning consists of strategies designed to minimize tax liability and the effects of cash flows on the business in terms of when it is most beneficial for a business to pay its tax liability without incurring any tax penalty (Salawu \& Adedeji, 2017). Fagbemi, et al (2019) reveal that tax planning involves a critical understanding and application of relevant tax shelters and incentives of business units, which includes the incentives given in recognition of the pioneer status, the rules applied to the commencement and cessation of a business, the allowances given in respect of the acquisition of the asset used for the purpose of the business, investment in rural areas and the location of the business, roll-over as applied to the sales of the items chargeable to capital gain tax, tax exemption on interest on a loan, loss reliefs (Ogundajo \& Onakoya, 2016).

Corporate governance structure is a major factor that affects tax planning strategies in organisations. According to Aburajab et al (2019), corporate governance interacts with tax planning because it is a mechanism employed by firms to discourage the behaviours that are against the interests of the various stakeholders of the firm and ensure that the quality of management decisions and transparency of issues associated with corporate income tax. Ogbeide and Obaretin, (2018) suggested that corporate governance mechanisms to minimize tax payments no doubt is borne out of effective and efficient tax management practice for the purpose of achieving shareholders' wealth in a business entity while being cautious of sliding into the trap of tax evasion. Ahmed and Khaoula (2013) opine that, corporate governance plays a strategic role in corporate tax planning. This is because corporate governance is a mechanism that monitors manager's behaviour and to identify and implement tax planning practices. Zemzem and Fluohi (2016) observe that corporate governance mechanism consist of board size, managerial ownership, board independence, executive compensation, board diversity, audit committee size and independence amongst others. Corporate tax planning strategies are generally designed to minimize tax liability that includes tax avoidance and tax savings (Ogbeide \& Obaretin, 2018; Chytis, et al 2019; Mappadang, 2019; Tijjani \& Peter; 2020; Bashiru, et al, 2020). Therefore, a naira saved through an effective and efficient tax planning practice is additional naira available to shareholders because tax planning leads to tax savings (Aburajah, et al, 2019). There is the need to investigate whether corporate governance mechanisms have an impact on corporate tax planning in Nigeria. Prior studies on corporate governance and tax planning show conflicting argument that necessitates further investigation in the literature in both developed and emerging economies (Abdul Wahab and Holland, 2012; Appolos, et al, 2016; Păunescu, et al, 2016; Ogundajo, et al, 2016; Mohammad, 2017; Auerbach, et al, 2017; Mais \& Patminigih, 2017; Salawu \& Adedeji, 2017; Ogbeide \& Obaretin, 2018; Ayers, et al, 2018; Kadir, 2018; Aburajah, et al, 2019; Chytis, et al 2019; Mappadang, 2019; Tijjani \& Peter; 2020; Ogbeide \& Obaretin, 2018; Putri, et al 2018; Imuetingan, et al 2019; Bashiru, et al, 2020).

The mixed results of these prior studies could be as a result of differences in jurisdictional characteristics, corporate governance codes, tax laws, institutions, income patterns and board of director's behaviour. Also, the issue of a number of methodological problems, failure to test for endogeneity, unobserved firm heterogeneity, not controlling for corporate governance factors affecting tax planning, small sample size and the use of narrow measures for tax planning. These are some of the gaps observed in prior studies. This current study investigates the effects of corporate governance characteristics (board size, board 
compensation, gender diversity, board financial expertise and board meetings) on tax planning proxies (tax savings and book-tax difference) of listed pharmaceutical firms in Nigeria. The specific objectives include the following:

1. to investigate the relationship between board size and tax savings of listed pharmaceutical firms in Nigeria;

2. to assess the relationship between board compensation compensation and tax savings of listed pharmaceutical firms in Nigeria;

3. to evaluate the relationship between gender diversity and tax savings of listed pharmaceutical firms in Nigeria;

4. to investigate the relationship between board financial expertise and tax savings of listed pharmaceutical firms in Nigeria;

5. to evaluate the relationship between board size and tax savings of listed pharmaceutical firms in Nigeria;

6. to investigate the relationship between board size and book-tax difference of listed pharmaceutical firms in Nigeria;

7. to assess the relationship between board compensation and book-tax difference of listed pharmaceutical firms in Nigeria;

8. to evaluate the relationship between gender diversity and book-tax difference of listed pharmaceutical firms in Nigeria;

9. to investigate the relationship between board financial expertise and book-tax difference of listed pharmaceutical firms in Nigeria;

10. to evaluate the relationship between board size and book-tax difference of listed pharmaceutical firms in Nigeria;

The following research questions guided this study:

1. What is the relationship between board size and tax savings of listed pharmaceutical firms in Nigeria?

2. What is the relationship between board compensation and tax savings of listed pharmaceutical firms in Nigeria?

3. What is the relationship between gender diversity and tax savings of listed pharmaceutical firms in Nigeria?

4. What is the relationship between board financial expertise and tax savings of listed pharmaceutical firms in Nigeria?

5. What is the relationship between board size and tax savings of listed pharmaceutical firms in Nigeria? 
6. What is the relationship between board size and book-tax difference of listed pharmaceutical firms in Nigeria?

7. What is the relationship between board compensation and book-tax difference of listed pharmaceutical firms in Nigeria?

8. What is the relationship between gender diversity and book-tax difference of listed pharmaceutical firms in Nigeria?

9. What is the relationship between board financial expertise and book-tax difference of listed pharmaceutical firms in Nigeria?

10. What is the relationship between board size and book-tax difference of listed pharmaceutical firms in Nigeria;

The following research hypotheses were tested in this study:

H01: There is no significant relationship between board size and tax savings of listed pharmaceutical firms in Nigeria.

H02: There is no significant relationship between board compensation and tax savings of listed pharmaceutical firms in Nigeria.

H03: There is no significant relationship between gender diversity and tax savings of listed pharmaceutical firms in Nigeria.

H04: There is no significant relationship between board financial expertise and tax savings of listed pharmaceutical firms in Nigeria.

H05: There is no significant relationship between board size and tax savings of listed pharmaceutical firms in Nigeria.

H06: There is no significant relationship between board size and book-tax difference of listed pharmaceutical firms in Nigeria.

H07: There is no significant relationship between board compensation and book-tax difference of listed pharmaceutical firms in Nigeria.

H08: There is no significant relationship between gender diversity and book-tax difference of listed pharmaceutical firms in Nigeria.

H09: There is no significant relationship between board financial expertise and book-tax difference of listed pharmaceutical firms in Nigeria.

H010: There is no significant relationship between board meetings and book-tax difference of listed pharmaceutical firms in Nigeria. 
British Journal of Management and Marketing Studies

ISSN: 2689-5072

Volume 5, Issue 1, 2022 (pp. 1-38)

\section{REVIEW OF RELATED LITERATURE}

\section{Conceptual Review}

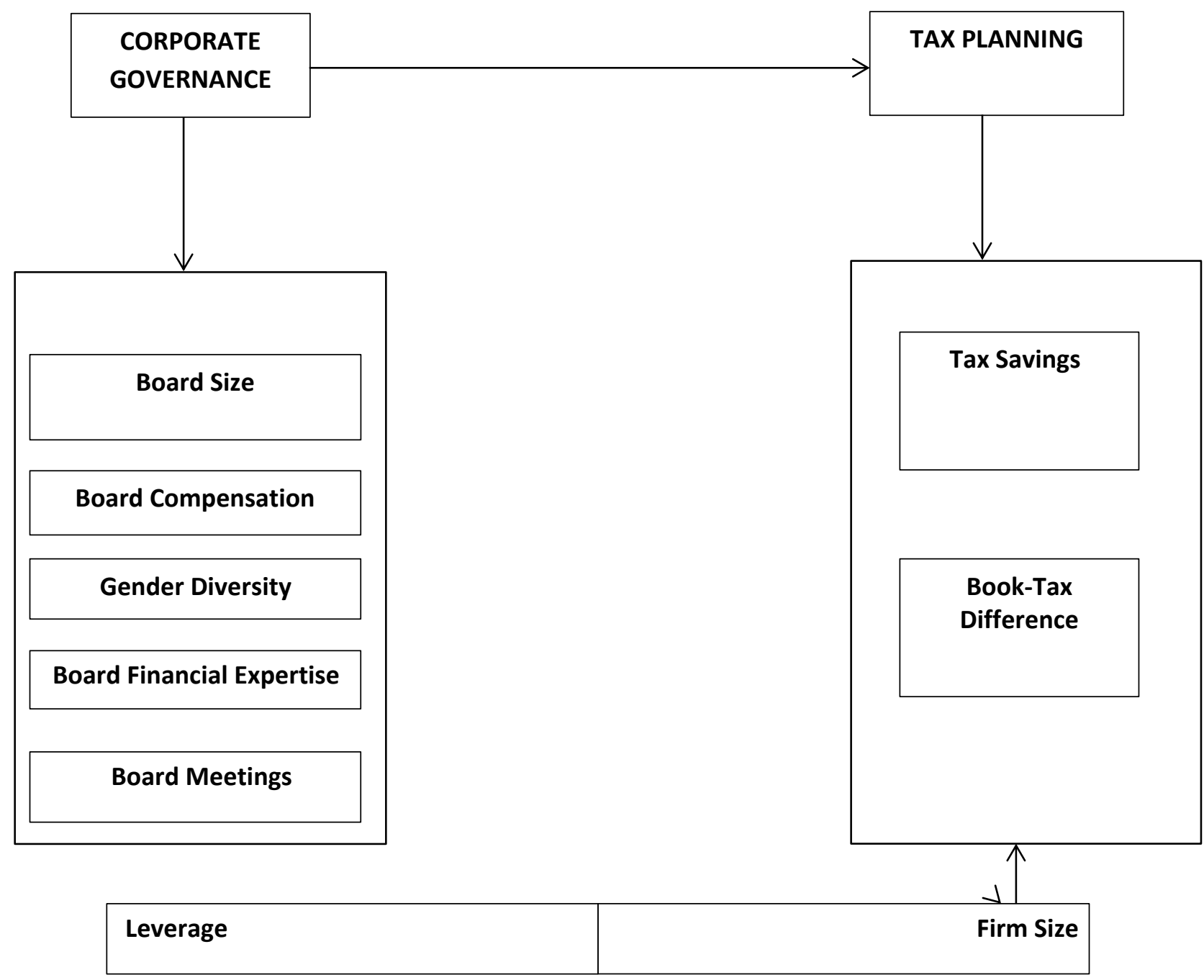

Fig. 1: Conceptual Framework of the Relationship between Corporate Governance and Tax Planning.

Source: Research Desk $\quad$ Ogbeide and Obaretin (2018); Aburajah, Maali, Jaradit and lsherti (2018); Mappadong (2019); Tijani and Peter (2020); Mgammel (2019). 


\section{Concept of Corporate Governance}

Corporate governance is the collection of linkages between the managers, shareholders, board of directors and other stakeholders of a firm. Hulya (2016) defined corporate governance as a means that ensures business is fairly, efficiently, effectively and transparently managed in order to achieve corporate goals through better practices and structures. According to Christina and Alexnader (2018). Corporate governance is defined as the processes and procedures utilised to direct and manage the activities and events of a firm with the objective of balancing the achievement of corporate objectives with the alignment of corporate behaviour to the expectations of society and accountability and transparency to shareholders and stakeholders. The major aim of good corporate governance is to ensure the efficient use of resources to reduce corporate fraud and mismanagement with the purpose of maximising shareholders wealth and aligning the conflicting interests of all stakeholders (Yimbila, 2017). Hasibuan and Khomsiyah (2019) noted that the good corporation governance reduces agency problems and improve corporate performance. Ying (2015) noted that previous studies have documented that a good corporate governance system serves as an effective mechanism in the mitigation of opportunistic behaviour of management; effectively alleviate agency problems mostly the agency conflicts between managers and owners; protect shareholders and ensure that investors are given a fair return on their investments (Nafti,et al, 2020; Belz, Hagen, \& Steffens, 2019; Chytis, et al 2019; Mappadang, 2019; Ogbeide, \& Obaretin, 2018; Mais, \& Patminigih, 2017).

Board Size: This is the number of individuals that constitute the board of directors of a company. The number of individuals that makes up the board of directors influences the advisory capacity of the board as well as its monitoring effectiveness. Lanis and Richardson (2011) suggested that the size of the board has a significant impact on tax planning. Mahenthiran and Kasipilai (2012) examined board composition and corporate tax avoidance and found a significant but negative partial association between board composition and corporate tax avoidance among Malaysian listed. Aliani and Zarai (2012) study revealed that no significant association between the size of the board and tax avoidance. Their investigation suggested that the number of directors does not affect the strategies for tax avoidance.

Board Compensation: Board compensation is used to indicate top employee's gross earnings in the form of financial rewards and benefits (Akewuosha \& Saka, 2018). Cordeiro, et al (2016) stated that executive compensation can be examined as a system of rewards that can motivate employees to perform efficiently. Compensation structure takes into consideration qualification, experience, attitude and prevailing rates in the labour market or industry (Ogbeide \& Akanji, 2016; Yu \& Van-Luu, 2016). According to Olaniji, et al (2017), board compensation is the financial compensation and other non-financial awards received by executives from their company for their service to the organization. It is typically a mixture of salary, bonuses, shares of or call options on the company stock, benefits and perquisites, ideally configured to take into account government regulation, tax law, the desires of the organization and the executive, and rewards for performance. The research conducted by Tandean and Winnie (2016) on corporate governance and tax avoidance revealed a negative and insignificant relationship between executive compensation and effective tax rate in Indonesia. Gaertner (2014) noted a negative relationship between after-tax incentives of directors and effective tax rate. However, the employment of after-tax measurement in directors' remuneration brings about higher tax savings for firms. On the other the hand, 
Razali et al (2019) stated that directors' remuneration is a factor that influences the motivation of companies to pursuing tax planning activities. According to Lestari and Wardhani (2015), there is a positive relationship between tax planning and directors' compensation. Razali, et al (2019) found a positive and significant relationship between directors' compensation and tax planning activities.

Gender Diversity: Gender diversity is also an important corporate governance attribute. This explains the number of women on the board. Literature on gender studies stated that board diversity could improve the effectiveness and efficiency of the board and that firm can benefit from the existence of women in the board of directors (Salawu \& Adedeji, 2017). Vacca, et al (2020) argue that gender diversity is important to the process of decision making because it ensures that firms have good governance structure; achieve ethical and strategic process of decision making; better financial and economic efficiency and more transparency (Nadeem, et al 2017; Cabeza-García, et al , 2018; Ahmadi, et al 2018). Reguera-Alvarado, et al (2017) explains that gender diversity allows the board to establish a proper strategy by considering the interests of corporate stakeholders. The effect of women on the corporate decision making process on tax planning practices provides mixed results. Lanis, et al (2017) explain that women as members of the board of directors are not involved in tax planning activities. Nwezoku and Egbunike (2020) found that there is a positive and significant relationship between gender diversity and tax aggressiveness of listed healthcare manufacturing firms in Nigeria. Salawu and Adedeji (2017) investigation of corporate governance and tax planning revealed a negative and significant relationship between board diversity and tax planning of listed non-financial firms in Nigeria. Their study implies that an increase in the proportion of women on the board will decrease effective tax rate. Hoseini and Gerayli (2018) study revealed a negative and significant relationship between gender diversity and the level of corporate tax avoidance using effective tax rate and book-tax difference.

Board Financial Expertise: Board financial expertise is the individual financial skills and competences of board members that can be developed through experience and education. (Khan \& Ali, 2018). The financial knowledge, experience and qualification of board members are significant resource of firm and their soundness of judgement and higher level of intellectual ability can enhance the performance of firms (Khan \& Ali, 2018). The monitoring and oversight function of the board of directors can be effectively be achieved by board members with adequate financial expertise and qualification (Khan \& Ali, 2017). Berger et al (2014), state that educational level of board members enhances the practices of corporate governance. Thus, studies disclosed positive relationship between board financial expertise and firm performance (Khan, et al 2018; Khan \& Ali, 2018). Setiyono and Tarazi (2018) indicate that education diversity and expertise of board members leads to higher income volatility and leverage risk. King et al. (2016) further disclose that CEOs with MBA degrees have significant effects on firm's performance. While other studies disclosed negative relationship between board financial expertise and firm performance.

Board Meetings: The number of board meetings is an indicator of the effectiveness of the board of directors in managing the firm. According to Madawaki and Amran (2013), this is due to the fact various users of financial statements perceive fewer meetings as a sign of less commitment and insufficient time to oversee the effective and efficient management of the organization and also the tax planning activities. Peter et al (2020) stated that meeting is a major means of carrying out the business of the board and strategically achieving the objective of the firm. They argue that during such board meetings members of the board of 
directors would discuss important issues of cost minimizing through tax planning practices. Barros and Sarmento (2020) stated that board meetings are useful mechanism for increasing corporate governance quality, which improves tax optimization. The study of board attributes and tax planning in Nigeria by Peter et al (2020) revealed that board meetings has a nonsignificant positive influence on tax planning. In a study conducted by Barros and Sarmento (2020) in the United Kingdom suggested that board meetings influences tax planning negatively. Their study revealed that the higher the number of board meetings decreases a firms tax liability.

\section{Concept of Tax Planning}

Tax planning is the process by which taxpayers utilize the loopholes in the tax laws in order to minimize tax liabilities. According to Abdul Wahab (2016), the concept of tax planning can be examined from four perspectives. Tax planning is complex, tax planning does produce several benefits, tax planning is underutilized and several individuals are unaware of the merits of tax planning. According to Uchendu, et al (2016), tax planning involves those strategies that are designed to reduce the corporate tax liability of companies and the cash flow effects on the business in terms of when it is most beneficial for a business to settle its tax liability without incurring any penalty (Chukwudi, et al , 2020). Ogundajo and Onakoya (2016) noted that tax planning involves the detail understanding and application of loopholes in relevant tax laws by taxpayers for the purpose of minimizing tax liability. Nwaobia, et al (2016) suggest that effective corporate tax planning practices does minimize the effective tax rate to the level that it falls below the statutory tax rate. They further argued that tax planning practices provides positive effects on the cash flow of companies and hence improves firms after tax rate of returns. Chukwudi, et al (2020) noted that tax planning is a practice consistent with the relevant tax laws to minimize the tax liability of companies using the effective tax rate. Soufiene, et al (2016) state that tax planning practices involves the minimization of corporate income tax for the purpose of maximization the after tax income. Ilaboya, et al (2016) noted that tax planning applies exemptions, deductions, rebates, reliefs and other tax incentives allowed in the tax laws for the sole aim of reducing corporate tax liability. Chen, et al (2010) opine that tax planning is an important practice employed by managers of corporations to minimize tax liabilities that reduces the returns of companies and shareholders. Mgammal and Ismail (2015) argued that tax planning is the suitable option within relevant tax laws to minimize corporate tax liability. They further stated that tax planning can be achieved by using different tax rates between separate jurisdictions and economic activities as well as tax incentives provided within the relevant tax laws.

The American Institute of Certified Public Accountants (2015), note that there are two major objectives of tax planning. The first objective is to reduce the total income tax liability and the second is achieving financial planning with little tax outcomes (AICPA, 2015). According to Mgammal and Ismail (2015), the aims of tax planning can be achieved with three major strategies. The first objective is the decrease in income tax liability as a result of the proper arrangement or a given financial transaction. The second entails the shifting the time of taxable event and the third involves shifting income to another taxpayer (AICPA, 2015).

There are several measures used in tax planning research to measure the concept of tax planning. According to Abdul Wahab (2010), prior tax planning studies apply several measures of tax planning using both private and public data. Previous researchers such as Hanlon \& Heitzman, (2010), Abdul Wahab (2010), Mgammal and Ismail (2015), Rego and 
Wilson, (2012), Moahmmad (2017) used different measures to explain tax planning on the basis of data accessibility and interest. Mgammal and Ismail (2015) argue that in the measurement of the result of tax planning, the measure can be appropriate due to the exhibition of a gap between taxes burden-based book reports and taxable income based. They further noted that book tax gaps are the popular measures utilized by researchers. Mohammad (2017) noted that the measures listed by Hanlon and Heizman (2010) are summarized as falling into four classes of effective tax rate measures, discretionary or abnormal measures, unrecognized tax benefits and tax shelter firms. The effective tax rate measures are broad measures that cover both permanent and temporary differences while the other three measures all capture specific forms of tax planning.

Effective Tax Rate and Tax Savings Measure: This is used to explain how much firms pay taxes as a percentage of pre-tax incomes (Johnson, et al, 2012). Mohammad (2017) noted that effective tax rate measures the average tax rate per naira of pre-tax income. Similarly, Izevbekhai and Odion (2018) state that the effective tax rate for companies is derived as the total tax expense divided by the earnings before tax. According to Mohammad (2017), the effective tax rate is the most effective measure of tax planning. She noted that effective tax rates measures include GAAP ETR, cash ETR and long-run ETR. The effective tax rate (ETR) approach compares the applicable statutory tax rate (STR) of a given firm with the ETR. The unexplained excess of the STR over the ETR is called the outcome in tax planning (tax savings).

Book-Tax Difference: The book tax difference is also a measure used by researchers and other authority to measure tax planning. According to Abdul Wahab (2016), book-tax difference is a measure used at firm level to measure tax planning due to the absence of tax return data. Book-tax difference measures the difference between financial statement income and federal taxable income (Huang \& Wang, 2013). Abdul Wahab and Holland (2015), booktax difference measures the difference between taxable income and accounting income. Chukwudi, et al (2020) noted that book-tax differences as a measure of tax planning arise because accounting income in the financial statement is intended to evalaute the performance of management. On the other hand, taxable income is designed to ascertain the amount of corporate tax to be paid. Abdul Wahab (2016) stated that book-tax difference can be disaggregated into permanent difference and temporary difference.

\section{Theoretical Review}

This study is anchored on agency theory and Hoffman tax planning theory.

Agency Theory: This theory was advanced by Jensen and Meckling (1976) and Fama and Jensen (1983). Izedonmi (2016) suggested that agency problem arises in a situation where the principal (owners, shareholders) employs the agent (board/management) to undertake number of duties on behalf of the owners for a reward. Olugbenga, et al (2014) state that agency theory is the application of game theory to the explanation of the circumstances in which a person (the agent) acts on behalf of the principal for the advancement of the principal's objectives. According to Adeyemi, et al, (2019), agency theory is a unit of finance and accounting that explains the conflicts of interest between stakeholders with diverse interests in the same asset. Ogundayo and Onakoya (2016) noted that this theory explains the ability of tax planning practice to transform into the improvement of after tax returns due to agency problem of managerial opportunism. Scholars have criticized agency theory. According to 
Dallas (2011), the agency theory fails to identify which social returns need to be pursued by organisations given their focus on maximization of profit. The author also stated that the theory do not set the rules defining an acceptable level of risk (Narbel \& Muff, 2017). The behavior of shareholders attitude towards tax planning may depend on the costs and benefits involved in corporate tax planning. According to Richardson, et al (2013), tax planning is not an absolute policy prescription for corporate entities, but it depends to a large extent on the benefits involved in corporate tax planning. The authors further provide that marginal benefits of tax planning to shareholders include tax savings while the marginal costs include potential tax fines and penalties to be imposed by the relevant tax authorities. According to Desai \& Dharmapala, (2006) in Abujarah et al (2019), there are also potential agency costs in the form of rent extraction by managers due to the complimentary relationship between tax planning and managerial diversion. Therefore, corporate tax planning can be studied within agency theory (Mohammad, 2017).

Hoffman Tax Planning Theory: The Hoffman tax planning theory was developed by Hoffman (1961) in (Akintoye, et al, 2020). According to Fagbemi, et al (2019), Omesi and Appah (2021), the Hoffman tax planning theory explains the need to minimise company income tax income without affecting the accounting income. Ogundajo and Onakoya (2016), Akintoye, et al (2020) stated that this theory enumerate the complexities and loopholes in tax laws due to the hidden intentions and concluded that good tax schemes perform with precise legal concepts and compliance with these laws by corporate entities provides tax savings. Abdul-Wahab and Holland (2012); Abdul-Wahab (2016) and Akintoye, et al (2020) stated that this theory provided important four principles of corproate tax planning. These principles are the complex nature of tax planning, benefits of tax planning, the lack of proper utilization of tax planning and people are not aware of the advantages of tax planning. Peter et al (2020) noted that because of complex nature of tax policy and systems, the loopholes in the tax laws cannot be avoided giving tax payers an advantageous tax position. Hoffman (1961) in Omesi and Appah (2021) noted that tax planning can only be sustained for a short duration if the tax planning practices are not dynamic in the sustenance of the tax management strategies (Akintoye, et al, 2020; Abdul-Wahab, 2016). This theory is important to this study because companies that maximizes the loopholes in tax laws and which maintain an optimal leverage thus having tax shield on the deductible interest tends to reduce its tax burden and improves its after tax income.

\section{Empirical Review}

There are several previous empirical investigations on the association between corporate governance mechanisms and tax avoidance in developed and developing countries. Some of these studies are reviewed below with a view to observe the trends of the findings and the gaps in literature.

Yuniarsih (2018) carried out an investigation on accounting conservatism and corporate governance mechanism on tax avoidance in Indonesia. The study employed ex post facto research design. The data for this study was secondary obtained from the published financial statements of sampled manufacturing companies listed on the Indonesian Stock Exchange for the period 2014 to 2016. The investigation employed random sampling technique for the purpose of sampling technique. The data obtained from the annual reports were analysed using descriptive and inferential statistics. The inferential statistics was guided by multiple regression analysis. The result obtained from the hypotheses testing revealed that accounting 
conservatism does not influence tax avoidance, managerial ownership negatively affects tax avoidance, institutional ownership does not affect tax avoidance and audit quality also does not affect tax avoidance in Indonesia listed manufacturing companies. This investigation was conducted in a different context and therefore the results cannot be generalized in this context. Also, the study employed a different concept.

Zhu, et al (2019) investigated the corporate tax avoidance and firm performance in Ghana. The study utilized ex post facto and correlational research design. The data for the study was collected from the annual financial statements of the companies listed on the Ghanaian Stock Exchange for the period under review. The independent variable was corporate tax avoidance and the dependent variable was return on assets. The study controlled for size, inventory intensity, capital intensity and board independence. The study adopted purposive sampling technique and the data obtained were analysed using descriptive and inferential statistics. The inferential statistics was guided by standard ordinary least square regression model. The result obtained from the hypotheses test revealed that a negative association between corporate tax avoidance and return on assets. This study was conducted in a different context and the concepts are of tax avoidance was used on firm performance.

Ogbeide and Obaretin (2018) studied corporate governance and tax aggressiveness of quoted non-financial companies in Nigeria for the period 2012 to 2016. The study utilized longitudinal and causal effect research designs. The study employed secondary sources of data collection from the annual reports of eighty-five sampled companies from the total population of one hundred and sixteen. The dependent variable was tax aggressiveness measured with effective tax rate and the independent variables was corporate governance that was measured with board size, board independence, ownership concentration, and board gender diversity. The data obtained from the secondary sources was analysed using descriptive and inferential statistics. The inferential statistics consists of general method of moment after diagnostic and unit root tests. The result from the statistical tests suggests that corporate governance significantly affects tax aggressiveness. Their study specifically revealed that ownership concentration and managerial ownership positively and significantly affects effective tax rate while board size showed negatively and significantly on effective tax rate. Also, board gender diversity and board independence showed a negative and significant effect on effective tax rate of quoted non-financial companies in Nigeria for the period under review. This study used tax aggressiveness which is different from tax planning as used in the present study.

Aburajah, et al (2019) carried out a study on board of directors' characteristics and tax aggressiveness in Jordan. The study employed ex post facto and correlational research design. The study population consisted of all listed companies in Jordan while the sample of one hundred and twenty nine companies. Secondary data was used for data collection from the annual financial statements of sample companies. The dependent variable was tax aggressiveness measured with effective tax rate and independent variable board of directors' characteristics of board composition, board independence and CEO duality with size and return on assets as control variable. The data collected from the secondary data was analysed using descriptive and inferential statistics. The inferential statistics was logarithmic regression model. The result suggest that board composition and board independence showed a negative association with tax aggressiveness while board duality revealed a positive association with tax avoidance. The control variables of return on assets and firm size showed 
a positive association with tax avoidance. This study was conducted in a different context and also the concept of tax aggressiveness is not the same as tax planning.

Mappadang (2019) investigated corporate governance mechanism on tax avoidance and firm value of listed companies in Indonesia Stock Exchange for the period 2013 to 2016. The study adopted ex post facto and correlational research design. The data for the study was collected from the published annual reports of the listed companies. The population consisted of all manufacturing companies while a sample of eighty seven companies and purposive sampling methods was applied. The independent variable was measured by independent commissioners, institutional ownership, and the board of commissioners while the dependent variable was tax avoidance and firm value. The data collected from the annual reports was analysed with descriptive and inferential statistics. The inferential statistics was guided by partial least square regression analysis. The result revealed that corporate governance positively and significantly affects firm value while it shows a negative and significant association with tax avoidance. Also the result showed a positive and significantly affects firm value. This study was carried out in a different context and also the study focused on tax avoidance and firm value while the current study deals on tax planning.

Chytis, et al (2019) investigated tax avoidance, company characteristics and corporate governance in Greece. The study adopted ex post facto research design and the data was collected from the annual reports of listed companies in Greece for the period 2011 to 2015. The population of the study comprised of all listed company and the sample consisted of fifty six companies quoted on the Athens Stock Exchange. The independent variable consisted of board independence, audit quality, concentration of ownership with financial variables such as capital employed, leverage, liquidity and company size while the dependent variable was effective tax rate. The secondary data of the study was analysed with descriptive and inferential techniques. The inferential statistics employed random effect method. The results revealed that cash effective tax rate positively and significantly influence company size and a significant negative association with capital employed. The study therefore showed no significant association between corporate governance and tax avoidance. This study was conducted in a different context.

Hasibuan and Khomsujah (2019) carried out a study of corporate social responsibility, corporate governance and tax aggressiveness in Indonesia. The study employed ex post facto and correlational research designs. The population comprised of all companies quoted on the Indonesia stock exchange for the period 2014 to 2017. The study employed purposive sampling technique with a sample size of two hundred and four. The data for this study was secondary data obtained from the annual reports and financial statements of sampled companies. The dependent variables was tax aggressiveness measured with effective tax rate while the independent variable consisted of corporate social responsibility and corporate governance with several control variables such as company size, leverage, and returns on assets. The secondary data was analysed with descriptive and inferential statistics. The inferential statistics was based on a multiple regression model. The results obtained from the regression model showed that corporate social responsibility positively influences tax aggressiveness and corporate governance does not influence tax aggressiveness. Also corporate governance has no influence on the moderation of corporate social responsibility and tax aggressiveness. This study was conducted in a different context and the concept of tax aggressiveness is not the same as tax planning. 
Putri, et al (2018) carried out a study on corporate governance and tax planning. The study used exploratory research design and the data was collected from the financial statement of the sampled firm. The study employed non-random sampling technique of purposive sampling method. The study dependent variable was effective tax rate and the independent variable was institutional ownership, independent directors and leverage ratio while the control variables were company size, return on assets and capital intensity ratio. The data collected from the financial statement was analysed with descriptive statistics, diagnostic tests and multiple regression analysis using ordinary least square method. The result from the multiple regression analysis suggested no relationship between independent directors and institutional ownership on effective tax rate while leverage positively influences effective tax rate. This study was conducted in a different context.

Akintoye, et al (2020) investigated tax planning strategies and profitability of listed manufacturing firms in Nigeria for the period 2008 to 2017 using ex post facto research design. The population of the study consisted of fifty-two (52) firms with a sample size of forty-six (46) firm calculated using Taro Yamini's model. The study employed secondary sources of data collection from the annual reports of the sample firms. The data obtained from the published financial statements was analysed with descriptive and inferential statistics. The multiple regression analysis revealed no significant association between tax planning and return on assets (ROA) of listed manufacturing firms in Nigeria. Their study further suggested that tax planning strategies have both positive and negative association on the financial performance of listed manufacturing firms in Nigeria. This study focused on different concepts compared to that employed in the current study.

Timothy, et al (2020) examined corporate tax planning, board compensation and firm value in Nigeria for the period 2008 to 2015 . The study adopted ex post facto research design. The study population consisted of non-financial and non-oil and gas firms listed on the Nigerian Stock Exchange (NSE) while the sample consisted of 71 firms from the population of the study for the period under review. The data for the study was obtained from the published financial statements of sample firms. The dependent variable (return on assets) and independent variable (effective tax rate) while the control variables (firm size and leverage). The secondary data was analysed with descriptive and inferential statistics such as correlational and regression analysis. Their result suggests a positive and significant association between tax planning practices and firm value of listed non-financial firms in Nigeria. This study focused on different concepts compared to that employed in the current study.

Tijjani and Peter (2020) examined ownership structure and tax planning of quoted nonfinancial firms in Nigeria. The study employed ex post factor and correlational research design. Secondary data was used for the purpose of data collection from the annual reports of sampled companies for period 2008 to 2017. The study population consisted of 106 nonfinancial firms and a sample of 46 non - financial firms was used for the purpose of data analysis. The dependent variable of tax planning was measured with effective tax rate, the independent variables was measured with managerial ownership, institutional ownership and foreign ownership, while the control variables consisted of profitability and leverage. The data obtained from the annual reports were analysed with descriptive and inferential statistics. The inferential statistics employed panel regression analysis. The result from the regression analysis suggested a positive and significant relationship between managerial and institutional ownerships and tax planning while foreign ownerships revealed a negative 
relationship with tax planning. This study differs from the current study because only ownership structure (managerial ownership, institutional ownership and foreign ownership) on tax planning.

Kadir (2018) carried out a study on corporate governance mechanisms on tax avoidance listed manufacturing companies in Nigeria. The study employed ex post facto research design and the population consisted of 86 manufacturing firms while purposive sampling techniques was used to obtain a sample size of 23 firms. The study obtained secondary data from the annual reports of the sampled manufacturing companies. The data obtained were analysed with quantitative data analysis technique of descriptive and inferential statistics. The inferential statistics employed panel data regression analysis. The study results suggested that board independence and CEO duality are statistically significant with tax avoidance while independence of the board has a negative significant effect on tax avoidance. Also board size and audit committee independence are not statistically significant. This study focused on different concepts (tax avoidance) compared to that employed in the current study (tax planning).

Mgammel (2019) carried out a study on corporate tax planning and corporate tax disclosure of listed non-financial firms in Malaysia. The study employed quantitative research and data was collected from the annual reports of the 286 non-financial listed firms on Bursa Malaysia. The data for the study was obtained from the published financial statements of sampled non-financial firms for the period 2010 to 2012. The secondary data obtained from the financial statements were analysed with descriptive statistics and multivariate statistical analysis. The independent variable was tax planning while the dependent was tax disclosure. The multivariate statistical analysis revealed that tax planning positively influences tax disclosure of listed non-financial non- financial firms in Malaysia. This study focused on different concepts (corporate tax planning and tax disclosure) compared to that employed in the current study (corporate governance and tax planning).

Inua (2018) investigated the determinants of corporate effective tax rate of listed manufacturing companies in Nigeria. The study utilized ex post facto and correlational research design. The data for the study was obtained from the financial statements of sampled manufacturing firms for the period 2011 to 2016. The independent variable comprised board size, independence and control variables of firm size and leverage while the dependent variable effective tax rate was used. The population consisted of 170 listed firms as at 31 December 2016 while a sample of 30 firms with complete and consistent data was analysed with descriptive and inferential statistics. The inferential statistics employed panel ordinary least square. The result of the suggested that leverage, board independence and size affects effective tax rate negatively and significantly. Also, firm size negatively and insignificantly affects effective tax rate. This study focused on different concept (the determinants of effective tax rate) compared to that employed in the current study (corporate governance and tax planning).

Razali, et al (2019) carried out an empirical study on directors' remuneration and tax planning of listed firms in Malaysia for the period 2014 to 2016. The study employed ex post facto and correlational research designs. The population consisted of all listed non-financial companies and a sample of 500 firms was used for the analysis. The dependent variable was book-tax-difference and the independent variable consisted of cash directors' remuneration, non-cash directors' remuneration, company size, capital intensity and leverage board size. 
The study utilized secondary sources of data obtained from the published financial statement of sampled firms. The data collected from the financial statement was analysed with descriptive and inferential statistics. The inferential statistics was panel regression analysis. The result revealed a positive and significant relationship between cash remuneration, firm size and board size with book-tax difference. On the other hand, the study demonstrated a negative relationship between non-cash remuneration, leverage and book-tax difference.

Imuetinyan, et al (2019) investigated board characteristics, firm performance and tax planning of listed food manufacturing sector in Nigeria for the period 2008 to 2017. The study utilized ex-post factor research design. The population consists of food manufacturing companies and a sample of six firms was used for the purpose of analysis. The study used secondary sources of data collection from the published financial statements from the sampled firms. The dependent variable was tax planning and the independent variables were female directors, board size, board independence while the control variables were firm size and performance. The data collected was analysed using multiple regression analysis of Generalised Least Square (fixed effects) regression. The results revealed a negative association between that female directors, board size, board independence and firm size with tax planning. On the other hand, return on assets positively affects tax planning. The results from the Generalised Least Square regression revealed that female directors and board size negatively and significantly affects tax planning. On the other hand, board independence and return on assets revealed a negative and no significant influence on tax planning while firm size revealed a positive and no significant influence on effective tax rate.

Bashiru, et al (2020) investigated corporate governance attributes on tax planning of listed Nigerian conglomerate firms for the period 2014 to 2018. The study employed ex-post facto research design and a panel data was used from the published financial statements of the sampled firms for the period under review. The population of the study consisted of all conglomerate firms listed on the Nigerian Stock Exchange for the period under review which also represent the sample size. The dependent variable was effective tax rate and the independent was board size and CEO tenure while firm size was utilized as control variable. The data collected from the published financial statement were analyzed using a panel regression technique to evaluate the relationship between independent, dependent and control variables. Hausman specification test was conducted to choose between fixed and random effect estimation and the results revealed a negative and significant relationship between CEO tenure, firm size and effective tax rate and a positive relationship between board size and effective tax rate.

Uniamikogbo, et al (2019) investigated corporate governance and tax aggressiveness of listed oil and gas marketing firms in Nigeria for the period 2013 to 2017. The study employed cross sectional research design. The study population and sample consisted of all the twelve firms listed on the exchange. The data used secondary data obtained from the audited financial statement of the sampled firms. The dependent variable proxied as effective tax rate while independent variable proxied as board size, CEO duality, gender diversity and ownership structure. The secondary data obtained from financial statements were analysed using univariate, bivariate and multivariate analysis. The multivariate analysis suggested that gender diversity and board size positively and significantly affects effective tax rate while CEO duality negatively and significantly affects effective tax rate. Also ownership structure negatively and insignificantly affects effective tax rate (tax aggressiveness) of listed oil and gas marketing companies in Nigeria. 
Ba'aba and Bashiru (2019) carried out a study of corporate governance and tax planning of listed companies in Nigeria and Malaysia for the period 2014 to 2018. The study utilized ex post facto and comparative research design. The population consisted of the six conglomerate companies listed on the Nigerian Stock Exchange. The secondary data for the study were obtained from the audited financial statements of the companies in Nigeria and Malaysia. The dependent variable was effective tax rate and the independent variable was board size and CEO tenure while firm size was the control variable. The data obtained were analysed using univariate (descriptive analysis) and multivariate (panel multiple regression analysis). The result from the analysis revealed that a negative and significant association between CEO tenure, firm size and effective tax rate and a positive association between board size and effective tax rate. The study concluded that corporate governance structure influences tax planning and Nigerian manufacturing firms pays high tax as compared to food and beverages firms in Malaysia.

Norita and Heritiansyah (2019) conducted a study of corporate governance, liquidity and corporate size on tax avoidance of logistics and transportation firms listed on the Indonesian Stock Exchange for the period 2012 to 2017. The study employed quantitative research design and secondary data were obtained from the published financial statements of sampled firms. The population of the study consisted of all logistics and transportation firms listed on the Exchange while the study employed non-probability sampling (purposive sampling) technique and a sample size of eighteen (18) companies was used. The dependent variable was tax avoidance while the independent variables were independent commissioners, managerial ownership, institutional ownership, liquidity, audit committee, size of directors, and company size. The data obtained from the published annual reports were analysed with univariate, bivariate and multivariate analysis. The multiple regression analysis indicated that independent commissioner, managerial ownership, company size, director's size and liquidity have no significant influence on tax avoidance while audit committee and institutional ownership significantly influences tax avoidance in Indonesia. The findings of their study further disclosed that all the variables had a significant influence on tax avoidance.

Dariuni, et al (2019) investigated corporate governance, ownership structure, social responsibility and tax avoidance in Iran for the period 2009 to 2015. The study employed descriptive - correlational research design. The population consisted of all listed firms in Tehran Stock Exchange and a sample of 162 companies was selected from the population of the study. The study employed secondary sources of data collection from the published annual reports of the sample companies. The dependent variable was effective tax rate. The independent variables consisted of family ownership, institutional ownership and government ownership. The moderator variables were board size, board of directors independence, audit firm size while the control variables were firm size, capital intensity, financial leverage and return on assets. The data from the annual reports were analysed with univariate, bivariate and multivariate analysis. The multivariate analysis (multiple regression analysis) disclosed that corporate governance attributes have a significant influence on the association between ownership structure and effective tax rate while family and institutional ownership negatively affects effective tax rate (tax avoidance) but government ownership showed a positive association. The study further disclosed that corporate governance attributes of board size, board independence and audit firm size influences ownership structure of corporate social responsibility positively. The study also revealed that firms with high institutional ownership 
negatively affect the association between corporate social responsibility and effective tax rate (tax avoidance).

Fernandez-Rodriguez, et al (2019) carried out a study of ownership structure and effective tax rate in Spain. The study employed quantitative research design (correlational research design). The data for this study was secondary data obtained from the annual reports of sampled firms. The population comprised of all Spanish listed and non-listed firms for the period 2008 to 2014. The sample consisted of 3169 firms of 208 state owned and 2961 privately owned firms. The study used effective tax rate (tax planning) as dependent variable while the independent variable was state and privately owned firms. The study also used control variables such as firm size, leverage, tangible assets, investment in research and development, inventory and profitability. The secondary data collected were analysed using descriptive statistics, correlation matrix and multiple regression analysis. The result disclosed a significant difference between states owned and privately owned firms on effective tax rates. The control variables of size, leverage, investment in research and development, profitability, firm age, foreign operations, and auditing influences the tax burden of privately ownership companies while leverage and capital intensity affects state owned companies.

Peter et al (2020) investigated board characteristics and tax planning of listed non-financial companies in Nigeria for the period 2008 to 2017. The study employed quantitative research and correlational research design for the period under review. The population consisted of 106 non-financial companies and the sample size consisted of 46 companies due to period and availability of data. The research obtained data from the published financial reports of sample companies for the period. The dependent variable tax planning proxied as effective tax rate while the independent variable proxied as board size, board independence, board meeting, gender diversity, foreign directorship and the control variable consisted of profitability, leverage and industry effect. The secondary data obtained were analysed with descriptive analysis, correlation matrix and multiple regression model. The result from the analysis suggested that board independence negatively and significantly affects tax planning; foreign directorship negatively and insignificantly affects tax planning, while gender diversity, board size and board meetings positively and insignificantly affects tax planning of listed non-financial firms in Nigeria. The study further indicated that profitability positively and significantly affects tax planning while leverage suggested negatively and significantly affects tax planning.

Ezejiofor and Ezenwafor (2020) carried out an investigation of corporate governance and tax avoidance of listed food and beverages companies in Nigeria for the period 2013 to 2019. The study employed ex post facto research design and the population consisted of 12 companies and 3 companies were excluded due to availability of data. The data for this study consisted of audited financial statement of sampled firms. The dependent variable tax avoidance was proxied using effective tax rate and independent variable corporate governance was proxied using CEO duality while firm size was a control variable. The secondary data obtained was analysed using univariate and multivariate analysis techniques. The result revealed that CEO duality significantly affects tax avoidance of food and beverages companies in Nigeria.

Evangelos et al (2020) investigated corporate governance mechanisms and tax planning of listed companies on the Athens Stock Exchange for the period 2011 to 2015. The study employed quantitative research design. The population consisted of all the listed firms on the 
stock exchange while the sample comprised of 55 non-financial firms listed on the stock exchange. The study employed secondary sources of data from the annual reports of sampled companies. The study employed effective tax rate as dependent variable while the independent variables were board independence, CEO duality, board size, ownership concentration, and audit firm size. The control variable for the study comprised of liquidity and leverage. Furthermore, the study utilized univariate (descriptive analysis), bivariate (correlation matrix) and multivariate (multiple regression model) analysis techniques. The result disclosed that a positive and significant association between board independence and effective tax rate while CEO duality revealed a negative association with effective tax rate. The findings also suggested that board size, audit firm size, leverage, liquidity and ownership concentration does not significantly affect effective tax rate of listed firms in Greece.

Tanko (2020) carried out a study of ownership structure and tax avoidance of listed consumer goods firms in Nigeria. The study employed quantitative research design of correlational research. The population consisted of all consumer goods firms and the sample size comprised 13 companies after the filtration process. The study utilized secondary sources of data collection from the annual reports of sampled firms. The dependent variable of the study was effective tax rate (tax avoidance). The independent variables consisted of managerial ownership, institutional ownership and foreign ownership while the moderator variable was return on assets. The study used four control variables namely leverage, firm size, and firm age. The data obtained from the secondary data were analysed with descriptive analysis, correlational matrix and multiple regression analysis (generalized least square). The findings of the study indicated a positive and insignificant association between managerial ownership and effective tax rate (tax avoidance), institutional ownership negatively and insignificant affects effective tax rate (tax avoidance) while foreign ownership positively and insignificantly influences effective tax rate (tax avoidance) of listed consumer goods firms in Nigeria. The result further disclosed that the control variables of firm size, firm age and leverage positively and insignificantly affects effective tax rate (tax avoidance). The moderator variable of return on assets indicated that managerial ownership positively and significantly affects effective tax rate while the moderator variable return on assets disclosed that institutional ownership positively and insignificantly impact on effective tax rate (tax avoidance) and the moderator variable of return on assets suggested that foreign ownership negatively and insignificant effects on effective tax rate.

Barros and Sarmento (2020) conducted a study of board meeting attendance and corporate tax planning in the United Kingdom. The study employed 74 companies listed on the London Stock Exchange for the period 2002 to 2015. The study used secondary sources of data obtained from Thomson Reuters Eikon. The dependent variable was cash effective tax rate while the independent variables consisted of board meetings, board attendance, CEO board member, solvency, quick ratio, capital intensity, inventory turnover, and size. The data obtained were analysed using univariate (descriptive analysis), bivariate (correlation matrix) and multivariate analysis (ordinary least square, fixed effect and random effect). The result of the study suggested that board meetings and attendance negatively affects tax avoidance for the period under review.

Omesi and Appah (2021) investigated corporate governance and tax avoidance of listed consumer and industrial goods firms in Nigeria for the period 2015 to 2019. Their study employed ex post facto and correlational research design. The population of the investigation consisted of fifty one firms and Taro Yamene sample size determination arrived at forty five 
firms. The study used secondary data from the annual reports of sampled firms. The study dependent variable was effective tax rate and the independent variable consisted of board size, board independence, audit committee, audit quality and ownership structure while the study utilised control ratios such as profitability, leverage, firm size, and growth, capital intensity. The data obtained from the published financial statements were analysed using univariate and multivariate analysis. The panel generalized methods of moments revealed that board independence, audit quality and ownership significantly affects tax avoidance whereas board size and audit committee does not significantly affect tax avoidance in Nigeria. The study concluded that there is mix relationship between corporate governance characteristics and tax avoidance.

Sunarto et al (2021) carried out a study of corporate governance and tax avoidance with profitability as a moderator variable in Indonesia for the period 2014 to 2018. The study employed ex post facto and correlational research design. The population consisted of commercial banks and cluster sampling was utilsied and purposive sampling techniques of 209 companies. The independent variable consisted of state ownership, independent boards, and audit committee while tax avoidance the dependent variable employed effective tax rate while profitability was the moderator variable. The study employed secondary data obtained from the annual reports of sampled companies. The secondary data was analysed with descriptive analysis, diagnostic tests and multiple regression analysis. The result suggested that institutional ownership and independent directors do not affect profitability. Also profitability do not affect tax avoidance. The study further revealed that institutional ownership and audit committee affects tax avoidance positively. Also profitability does not mediate the influence of institutional ownership, independent directors and audit committee on tax avoidance. The study concluded that there is a significant impact of audit committee on profitability, institutional ownership and audit committee on tax avoidance.

Deef, et al (2021) conducted a study of foreign and managerial ownership on tax avoidance in Egypt. The study employed quantitative research design. The population comprised of the 100 non-financial firms listed on the Egyptian Stock Exchange while non-probability sampling (purposive sampling) was used to arrive at a sample size of 69 companies. The study used secondary data from the published annual reports of sample companies. The dependent variable tax avoidance (effective tax rate and book tax difference) while the independent variables consisted of foreign and managerial ownership while the control variables comprised of firm size, firm age, audit quality, profitability, firm industry and leverage. The secondary data collected from the annual reports were analysed using univariate (descriptive statistics), bivariate (correlation matrix) and multivariate (multiple regression) analysis. The multiple regression analysis showed that managerial ownership positively and significantly affects tax avoidance (effective tax rate) while foreign ownership negatively and insignificantly influences tax avoidance (effective tax rate). The control variables indicated that firm size and audit quality positively and significantly affects effective tax rate while leverage revealed a negative and significant association with effective tax rate. Furthermore, firm profitability, firm industry, firm age suggested no association with effective tax rate.

From the empirical studies reviewed, there is no consistency in the use of variable, sector and economy thereby resulting to disagreements in outcomes. The studies of Sunarto et al (2021), Omesi \& Appah (2021), Vu and Le (2021), Barros \& Sarmento (2020), Ezejiofor Ezenwafor (2020), Peter et al (2020), Ba'aba \& Bashiru (2019), Putri, et al (2018) have used effective 
tax rate as the measurement of tax planning. It is against this background that this study investigates the effects of corporate governance (board size, board compensation, gender diversity, board financial expertise and board meetings) on tax planning (tax savings and book tax difference) of listed pharmaceutical companies in Nigeria from 2015 to 2020.

\section{METHODOLOGY}

Research Design: This is the master plan of methods, approaches, techniques, variables, data source, evaluation methodology, timing and costing of all research activities for the purpose of achieving the research objectives (Appah, 2020). According to Ahiauzu and Asawo (2016), research design is the determination of how to conduct a research and the methods used. This study employed ex post facto and correlational research design. According to Kpolovie (2010), ex post facto research design is used to cover investigations that are done retrospectively (after the effect has occurred) to identify possible cause-and-effect relations between the variables under investigation through observations of existing conditions and inquisitively searching back historically for the causal factors.

Population of the Study: A research population is generally a large collection of individuals or objects that is the main focus of a scientific query. A research population is also known as a well-defined collection of individuals or objects known to have similar characteristics. According to Ahiauzu and Asawo (2016), population is the entire individual persons, group of persons, organizations, or things of interest that the researcher wishes to investigate. It is the complete set of cases or group members from whom relevant data could be raised. The population of this study consisted of all listed pharmaceutical companies in Nigeria from 2014 to 2020.

Sampling and Sample Size Determination: Sampling is a technique of selecting individual members or a subset of the population to make statistical inferences from them and estimate characteristics of the whole population. According to Ahiauzu and Asawo (2016), sampling is the process of selecting a sufficient number of elements from a population to represent the properties or characteristics of that population. This study used the census sampling to determine sample size of the listed pharmaceutical firms (Afrik Pharmaceuticals, Ekocorp, Evans Medical, Fidson Healthcare, Glaxosmithkline, Juli Nigeria Limited, May and Baker, Neimeth International Pharmaceuticals, Nigeria German Chemicals, Pharmadeko, Union Diagnostic and Clinical Services Plc).

Method of Data Collection: Data collection is the method of gathering relevant information for use in addressing the research questions and hypotheses testing (Bhattacherjee, 2012). Data used for the current study were extracted from the annual reports and accounts of the sampled pharmaceutical companies in Nigeria.

Operational Measures of Variables: Measurement is viewed as the integrative process of determining the integrity of information about constructs, concepts or objectives of interests and their relationships to a defined business problem or opportunity (Gravetter \& Forzano, 2019). 
Table 1: Measurement of Variables

\begin{tabular}{|c|c|c|c|c|}
\hline Variables & $\begin{array}{l}\text { Type of } \\
\text { Variable }\end{array}$ & Symbol & Measurement & Sources \\
\hline Tax Savings & Dependent & TAS & $\begin{array}{l}\text { The difference } \\
\text { between statutory } \\
\text { tax rate and effective } \\
\text { tax rate }\end{array}$ & $\begin{array}{l}\text { Hasibuan and } \\
\text { Khomsujah (2019); } \\
\text { Ogbeide and Obaretin } \\
\text { (2018); Chytis, et al } \\
\text { (2019) }\end{array}$ \\
\hline $\begin{array}{l}\text { Book Tax } \\
\text { Difference }\end{array}$ & Dependent & BTD & $\begin{array}{l}\text { The difference } \\
\text { between financial } \\
\text { statement income and } \\
\text { taxable income }\end{array}$ & Chukwudi et al (2020) \\
\hline Board Size & Independent & $\mathrm{BOZ}$ & $\begin{array}{l}\text { Total number of } \\
\text { directors on the board }\end{array}$ & $\begin{array}{l}\text { Hasibuan and } \\
\text { Khomsujah (2019); } \\
\text { Chytis, et al (2019) }\end{array}$ \\
\hline $\begin{array}{l}\text { Gender } \\
\text { Diversity }\end{array}$ & Independence & GED & $\begin{array}{l}\text { Number of women on } \\
\text { the board divided by } \\
\text { total number of } \\
\text { directors on the board }\end{array}$ & $\begin{array}{l}\text { Cabeza-García, et al, } \\
\text { 2018; Ahmadi, et al } \\
\text { 2018;Ogbeide and } \\
\text { Obaretin (2018); }\end{array}$ \\
\hline $\begin{array}{l}\text { Board } \\
\text { compensation }\end{array}$ & Independence & $\mathrm{BOC}$ & $\begin{array}{l}\text { Salary and benefits } \\
\text { received by executive } \\
\text { during the year }\end{array}$ & Razali et al (2019) \\
\hline $\begin{array}{l}\text { Board } \\
\text { Meetings }\end{array}$ & Independent & BOM & $\begin{array}{l}\text { Number of meetings } \\
\text { held by the board } \\
\text { within a year. }\end{array}$ & $\begin{array}{l}\text { Peter et al (2020); Barros } \\
\text { \& Sarmento (2020) }\end{array}$ \\
\hline $\begin{array}{l}\text { Board } \\
\text { Financial } \\
\text { Expertise }\end{array}$ & Independent & BFE & $\begin{array}{l}\text { The total number of } \\
\text { financial and } \\
\text { accounting experts on } \\
\text { the board/ total number } \\
\text { of directors }\end{array}$ & $\begin{array}{l}\text { Khan, Ismail \& Ali } \\
\text { (2017) }\end{array}$ \\
\hline Leverage & Control & LEV & $\begin{array}{l}\text { Total long term debt } \\
\text { divided by total assets }\end{array}$ & Zhu, et al (2019) \\
\hline Firm Size & Control & FIS & Log of total assets & Zhu, et al (2019) \\
\hline
\end{tabular}

Source: Compiled by the Researcher (2021)

Method of Data Analysis: Consistent with the positivist research philosophy and quantitative design, technique of inferential analysis in this study will be parametric statistics. This technique is associated with the use of quantitative models that seek to establish correlational relationship between two variables by using sample-based parameters as measures to infer about the population of the study. The data analysis will be executed in three distinct stages. Firstly, a univariate (or descriptive) analysis was executed, followed by bivariate analysis and lastly, multivariate analysis. The required functional relationship to test the developed hypotheses is presented as follows: 
Tax Planning $=\mathrm{f}($ Corporate Governance $)$

There are statements in the literature that several firm-specific features are also likely to affect the degree of tax planning by companies. Thus, in order to control for the influence of such firm-specific features the model was further specified as:

Tax Planning $=\mathrm{f}($ Corporate Governance, Firm Features $)$

The corporate governance variables included in the model are board size, board compensation, gender diversity, board financial expertise, board meetings while the control variables include return on assets, firm size, capital intensity, and leverage.

Since tax planning is represented by two proxies of tax savings (TAS) and book tax difference (BTD) we recast Eqn. (2) by decomposing it as follows:

TAS $=\mathrm{f}(\mathrm{BOZ}, \mathrm{BOC}, \mathrm{GED}, \mathrm{BFE}, \mathrm{BOM}, \mathrm{LEV}, \mathrm{FIS})$

$\mathrm{BTD}=\mathrm{f}(\mathrm{BOZ}, \mathrm{BOC}, \mathrm{GED}, \mathrm{BFE}, \mathrm{BOM}, \mathrm{LEV}, \mathrm{FIS})$

Therefore, in their respective empirical form, equation (2a) and (2b) are restated into the basic panel econometric form as:

TASit $=\beta_{0}+\beta_{1}$ BOZit $+\beta_{2}$ BOCit $+\beta_{3}$ GEDit $+\beta_{4}$ BFEit $+\beta_{5}$ BOMit $+\beta_{6}$ LEVit $+\beta_{7}$ FISit + zit --o-

BTDit $=\beta_{0}+\beta_{1}$ BOZit $+\beta_{2}$ BOCit $+\beta_{3}$ GEDit $+\beta_{4}$ BFEit $+\beta_{5}$ BOMit $+\beta_{6}$ LEVit $+\beta_{7}$ FISit + cit

\section{RESULTS AND DISCUSSION}

\section{Descriptive Statistics}

The descriptive statistical measures such as mean, median, mode, standard deviation, range, kurtosis, skewness, histogram and Jarque-Bera statistic, are calculated for each of the variables with a view to quantify the manifests construct of the variable in terms of central tendency, dispersion and shape of their distributions. In view of that, each of the variables and their descriptive properties are presented in table 2 collectively and represented individually below.

Table 2: Descriptive Statistics

\begin{tabular}{|c|c|c|c|c|c|c|c|c|c|}
\hline & TAS & BTD & $\mathrm{BOZ}$ & BOC & GED & BFE & BOM & LEV & FIS \\
\hline & 1.98029 & 5.71824 & 14.4086 & 4.68487 & 0.16817 & 14.1975 & 0.65858 & 0.58358 & 7.40912 \\
\hline Mean & 4 & 2 & 3 & 1 & 3 & 5 & 6 & 3 & 6 \\
\hline & 1.16695 & 5.65980 & 1.00000 & 4.83825 & 0.14290 & 0.30050 & 0.60210 & 0.58230 & 7.55265 \\
\hline Mec & 0 & 0 & 0 & 0 & 0 & 0 & 0 & 0 & 0 \\
\hline & 9.41520 & 18.9893 & 11761.0 & 6.14190 & 0.86450 & 2222.00 & 0.95420 & 1.50450 & 8.64780 \\
\hline Iaximun & 0 & 0 & 0 & 0 & 0 & 0 & 0 & 0 & 0 \\
\hline
\end{tabular}




\begin{tabular}{|l|c|c|c|c|c|c|c|c|c|}
\hline & - & & & & & & & \\
Minimum & 0.04790 & 2.98240 & 0.60210 & 0.07140 & 0.00000 & 0.14290 & 0.30100 & 0.19360 & 0.53440 \\
0 & 0 & 0 & 0 & 0 & 0 \\
\hline & 1.24020 & 3.47547 & & 0.92082 & 0.13768 & 6.37639 & 0.09479 & 0.19013 & 1.09222 \\
& 4 & 4 & 6.76485 & 3 & 3 & 9 & 0 & 1 & 4 \\
\hline Std. Dev. & & & & - & & & & & - \\
& 1.89735 & 0.69856 & 8.78576 & 1.88945 & 1.61112 & 12.5302 & 0.22875 & 1.57825 & 3.26678 \\
& 6 & 7 & 1 & 7 & 9 & 0 & 8 & 6 & 4 \\
\hline Skewness & 6.31733 & 4.30781 & 78.2499 & 9.34684 & 9.22605 & 158.006 & 4.68334 & 9.26766 & 20.4194 \\
Kurtosis & 5 & 4 & 0 & 6 & 9 & 1 & 6 & 3 & 4 \\
\hline Jarque- & 169.363 & 24.4157 & 39808.7 & 363.750 & 327.645 & 164366 & 20.2865 & 6301.68 & 328.314 \\
Bera & 7 & 3 & 0 & 9 & 1 & 1 & 0 & 5 & 4 \\
\hline & 0.00000 & 0.00000 & 0.00000 & 0.00000 & 0.00000 & 0.00000 & 0.00003 & 0.00000 & 0.00000 \\
Probability & 0 & 5 & 0 & 0 & 0 & 0 & 9 & 0 & 0 \\
\hline & 316.847 & 914.918 & 23053.8 & 749.579 & 26.9077 & 2271.60 & 105.373 & 202.043 & 93.3732 \\
Sum & 1 & 7 & 1 & 3 & 0 & 7 & 7 & 3 & 0 \\
\hline Sum Sq. & 538.429 & 1920.54 & $2.59 \mathrm{E}+0$ & 134.818 & 3.01407 & 490505 & 1.42863 & 166.058 & 5.74783 \\
Dev. & 8 & 8 & 8 & 6 & 9 & 1. & 0 & 2 & 4 \\
\hline Observatio & 77 & 77 & 77 & 77 & 77 & 77 & 77 & & 77 \\
\hline ns & & & & & & & & 77 & \\
\hline
\end{tabular}

Source: E-view output 2021

Table 2 presents the descriptive statistics of the dependent, independent and control variables statistics for this study. The mean values for tax savings, book-tax difference, board size, board compensation, gender diversity, board financial expertise, board meetings, leverage and firm size were 1.980294, 5.718242, 14.40863, 4.684871, 0.168173, 14.19755, 0.658586, 0.583583 , and 7.409126. The standard deviation of the variables was $1.240204,3.475474$, $6.76485,0.920823,0.137683,6.376399,0.094790,0.190131$ and 1.092224 . The skewness of the variables consist of $1.897356,0.698567,8.785761,1.889457,1.611129,12.53020$, $0.228758,1.578256$ and 3.266784 .

\section{Correlation Analysis}

Table 3 presents the correlation matrix of the variables wherein the degree and direction of relationships are indicated with the aid of Pearson's product moment correlation. Depending on the number of variables in any study, correlation matrix of study variables presents three (3) major distinctive bivariate relationships within the context of the study.

\section{Table 3: Correlation Matrix}

\begin{tabular}{|l|l|l|l|l|l|l|l|l|l|}
\hline & TAS & BTD & BOZ & BOC & GED & BFE & BOM & LEV & FIS \\
\hline TAS & 1.000000 & & & & & & & & \\
\hline BTD & 0.230152 & 1.000000 & & & & & & & \\
\hline BOZ & -0.026806 & -0.070504 & 1.000000 & & & & & & \\
\hline BOC & -0.055176 & 0.026033 & -0.008870 & 1.000000 & & & & & \\
\hline GED & -0.423153 & 0.076173 & 0.044608 & 0.074826 & 1.000000 & & & & \\
\hline BFE & 0.402141 & -0.152030 & -0.081716 & -0.033017 & - & 1.000000 & & & \\
\hline
\end{tabular}




\begin{tabular}{|l|l|l|l|l|l|l|l|l|l|}
\hline & & & & & 0.328295 & & & & \\
\hline BOM & -0.279094 & 0.343863 & -0.016082 & -0.046425 & 0.304043 & -0.120358 & 1.000000 & & \\
\hline LEV & 0.025300 & -0.066827 & -0.008904 & -0.006216 & 0.031469 & 0.031323 & 0.017501 & 1.000000 & \\
\hline FIS & -0.225142 & -0.114822 & -0.067224 & 0.033814 & 0.267873 & 0.171830 & 0.491343 & 0.033729 & 1.000000 \\
\hline
\end{tabular}

Source: E-view output 2021

The pair-wise correlation is mostly useful to the study by way of enabling the researcher to develop diagnostic capability in mitigating the effect of multi-collinearity by introducing biases in the standard error estimates of the coefficients. Multi-colinearity exists when the predictor variables are themselves highly correlated. If the variables have variance inflation factor (VIF) of above 10, then there is a strong indication of the existence of excess correlation. The relatively low level of correlation as indicated in the table clearly establishes that there is no multicollinearity in the model.

\section{Multivariate Analysis}

\section{Table 4: Result on Regression Equation of TAS}

Dependent Variable: TAS

Method: Panel EGLS (Cross-section random effects)

Date: $12 / 28 / 21$ Time: 05:14

Sample: 20152020

Periods included: 7

Cross-sections included: 10

Total panel (balanced) observations: 77

Swamy and Arora estimator of component variances

\begin{tabular}{crrrr}
\hline \hline Variable & Coefficient & Std. Error & t-Statistic & Prob. \\
\hline \hline BOZ & 2.176206 & 4.494306 & 0.484214 & 0.6292 \\
BOC & -1.486506 & 3.323205 & -0.044466 & 0.9646 \\
GED & -0.379515 & 0.099829 & -3.801670 & 0.0002 \\
BFE & 0.098930 & 0.067517 & 1.465263 & 0.1450 \\
BOM & -0.008032 & 0.026827 & -0.299399 & 0.7651 \\
LEV & -2.242105 & 3.260845 & -0.673531 & 0.5017 \\
FIS & -0.139014 & 0.087228 & -1.593683 & 0.1132 \\
C & 1.166653 & 0.124537 & 9.367956 & 0.0000 \\
\hline \hline
\end{tabular}

Effects Specification

S.D. Rho

\begin{tabular}{lll}
\hline \hline Cross-section random & 0.105703 & 0.7043 \\
Idiosyncratic random & 0.068492 & 0.2957 \\
\hline \hline
\end{tabular}

\begin{tabular}{llll}
\hline \hline \multicolumn{4}{l}{ Weighted Statistics } \\
\hline \hline R-squared & 0.720605 & Mean dependent var & 0.025523 \\
Adjusted R-squared & 0.697797 & S.D. dependent var & 0.130705
\end{tabular}




\begin{tabular}{lrll} 
S.E. of regression & 0.071852 & Sum squared resid & 0.758924 \\
F-statistic & 31.59476 & Durbin-Watson stat & 2.996505 \\
Prob(F-statistic) & 0.000000 & & \\
\hline \hline & Unweighted & Statistics & \\
\hline \hline R-squared & -0.003278 & Mean dependent var & 0.127146 \\
Sum squared resid & 3.813670 & Durbin-Watson stat & 0.198306
\end{tabular}

Source: E-view Output

According to the result shown in Table 4 the $\mathrm{R}^{2}$ statistic is 0.7206 while the adjusted $\mathrm{R}^{2}$ statistic is 0.6978 . This shows that $72.1 \%$ of systematic variation in tax savings (TAS) of the listed pharmaceutical manufacturing companies is explained by changes corporate governance. After adjusting the degree of freedom, 69.8\% variation in the TAS of the listed firms was explained by changes in corporate governance characteristics, leaving $30.2 \%$ unexplained due to the presence of stochastic error term. This suggests that corporate governance influences the TAS of listed pharmaceutical manufacturing firms in Nigeria.

The F - statistic, 31.59476 with a zero-probability value showed that the model satisfies the overall goodness-of-fit statistical test. It implies that TAS measures, inclusive of the control variables were able to predict TAS of the sampled listed pharmaceutical manufacturing companies in Nigeria. The Durbin-Watson statistic of 2.996505 indicates that there is no serial autocorrelation in the model. It suggests that the result is good for policy prescription. Similarly, the t-statistics and $\mathrm{R}^{2}$ statistics are not extremely high as to suggest the existence of Multicollinearity and Heteroskedasticity in the model. It further portends that the econometric model employed in this study satisfies both statistical and diagnostic criteria. It represents a good and consistent estimator, and hence useful for policy direction of the firms in Nigeria.

The individual coefficients show different levels of significances, giving rise to acceptance and rejection of each and every associated hypothesis. The result shows that a unit change in board size (BOS) and board financial expertise (BFE) increases the tax savings (TAS) of the listed pharmaceutical firms in Nigeria by 2.178206 and 0.009830 units but was statistically not significant at 5\% level. Similarly, a unit change in board compensation (BOC), gender diversity (GED), board meetings (BOM), leverage (LEV) and firm size (FIS) decreases tax savings (TAS) by $-1.486506,-0.379515,-0.008032,-2.242105$, and -0.139014 but board compensation (BOC), board meetings (BOM), leverage (LEV) and firm size (FIS) was statistically not significant at 5\% level while gender diversity (GED) was statistically significant at $5 \%$ level. 


\section{Table 5: Result on Regression Equation of BTD}

Dependent Variable: BTD

Method: Panel EGLS (Cross-section random effects)

Date: 12/28/21 Time: 06:09

Sample: 20152020

Periods included: 7

Cross-sections included: 10

Total panel (balanced) observations: 77

Swamy and Arora estimator of component variances

\begin{tabular}{crrrr}
\hline \hline Variable & Coefficient & Std. Error & t-Statistic & Prob. \\
\hline \hline BOZ & $-1.27 \mathrm{E}-05$ & $5.24 \mathrm{E}-05$ & -0.241947 & 0.8092 \\
BOC & $-5.08 \mathrm{E}-05$ & 0.000388 & -0.130882 & 0.8960 \\
GED & -2.296025 & 1.265889 & -1.813765 & 0.0718 \\
BFE & 3.609131 & 0.792626 & 4.553382 & 0.0000 \\
BOM & -0.107746 & 0.324985 & -0.331542 & 0.7407 \\
LEV & 0.000327 & 0.000108 & 3.013060 & 0.0030 \\
FIS & 0.576168 & 1.022348 & 0.563574 & 0.5739 \\
C & 4.942538 & 1.502115 & 3.290387 & 0.0013 \\
\hline \hline
\end{tabular}

Effects Specification

\begin{tabular}{lrc} 
& S.D. & Rho \\
\hline \hline Cross-section random & 1.699921 & 0.8193 \\
Idiosyncratic random & 0.798205 & 0.1807 \\
\hline \hline
\end{tabular}

Weighted Statistics

\begin{tabular}{llll}
\hline \hline R-squared & 0.644099 & Mean dependent var & 0.290857 \\
Adjusted R-squared & 0.582393 & S.D. dependent var & 0.887757 \\
S.E. of regression & 0.802724 & Sum squared resid & 94.72179 \\
F-statistic & 3.955822 & Durbin-Watson stat & 1.982798 \\
Prob(F-statistic) & 0.000028 & & \\
\hline \hline
\end{tabular}

Unweighted Statistics

\begin{tabular}{lrll}
\hline \hline R-squared & -0.038993 & Mean dependent var & 1.980294 \\
Sum squared resid & 559.4246 & Durbin-Watson stat & 2.166407 \\
\hline
\end{tabular}

Source: E-view output

According to the result shown in Table 5 the $\mathrm{R}^{2}$ statistic is 0.644099 while the adjusted $\mathrm{R}^{2}$ statistic is 0.582393 . This shows that $64.4 \%$ of systematic variation in book-tax difference (BTD) of the listed pharmaceutical manufacturing companies is explained by changes corporate governance. After adjusting the degree of freedom, 58.2\% variation in the BTD of the listed firms was explained by changes in corporate governance characteristics, leaving 
$41.8 \%$ unexplained due to the presence of stochastic error term. This suggests that corporate governance influences the tax planning of listed pharmaceutical manufacturing firms in Nigeria.

The F - statistic, 3.955822 with a zero-probability value showed that the model satisfies the overall goodness-of-fit statistical test. It implies that BTD measures, inclusive of the control variables were able to predict BTD of the sampled listed pharmaceutical manufacturing companies in Nigeria. The Durbin-Watson statistic of 1.982796 indicates that there is no serial autocorrelation in the model. It suggests that the result is good for policy prescription. Similarly, the t-statistics and $\mathrm{R}^{2}$ statistics are not extremely high as to suggest the existence of Multicollinearity and Heteroskedasticity in the model. It further portends that the econometric model employed in this study satisfies both statistical and diagnostic criteria. It represents a good and consistent estimator, and hence useful for policy direction of the firms in Nigeria.

The individual coefficients show different levels of significances, giving rise to acceptance and rejection of each and every associated hypothesis. The result shows that a unit change in board financial expertise (BFE), leverage (LEV) and Firm Size (FIS) increases the book-tax difference (BTD) of the listed pharmaceutical firms in Nigeria by 3.609131, 0.000327 and 0.576168 units but BFE and LEV was statistically significant at 5\% level while FIS was not statistically significant at 5\% level. Similarly, a unit change in board size (BOS), board compensation (BOC), gender diversity (GED), board meetings (BOM), decreases tax savings (BTD) by $-1.27 \mathrm{E}-05,-5.08 \mathrm{E}-05,-2.296025$ and -0.107746 but board size (BOS), board compensation (BOC), gender diversity (GED) and board meetings (BOM), was statistically not significant at $5 \%$ level.

\section{SUMMARY, CONCLUSION AND RECOMMENDATIONS}

The study investigated corporate governance characteristics and tax planning of listed pharmaceutical firms in Nigeria from 2015 to 2020. The study was anchored on agency theory and Hoffman tax planning theory. A review of relevant literature provided a relationship between corporate governance mechanisms and tax planning. This study measured corporate governance using board size, board compensation, board financial expertise, gender diversity and board meetings while tax planning was measured using tax savings and book tax difference. The multiple regression analysis suggested that board size and board financial expertise positively and statistically not significant with tax savings; board compensation and board meetings negatively and not statistically significant with tax savings while gender diversity negatively and statistically significant with tax savings. Also, the result revealed that board financial expertise positively and statistically significant with book-tax difference while board size, gender diversity, board compensation and board meetings negatively and statistically not significant with book tax difference. The study concluded that corporate governance characteristics (board size, board financial expertise, gender diversity, board meetings and board compensation) influences tax planning (tax savings and book-tax difference) of listed firms in Nigeria. Hence, the study recommended that: shareholders must preserve a structure to guarantee that the board is given financial incentives for effective tax planning. This will assist to solve the agency problem where management exploits shareholders through tax planning practices; listed companies in Nigeria should make sure composition of boards comprises mix of executive and non - 
executive directors who are professional accountants and tax experts. These set of professionals would be able to bring their professional training to positively impact important decision-making regarding tax planning strategies; the board remuneration committee of listed companies in Nigeria should purposefully and adequately compensate boards of directors in their effort to fundamentally minimize tax liability and also decrease agency costs; the board of directors of listed companies in Nigeria should restructure the board in terms of diversity. This would guarantee adequate mix of directors comprising of female and male, size, educational and professional training to perhaps impact financial performance, including tax planning.

The uniqueness of this investigation has suggestions for both academics and practitioners. For academics, unlocks viewpoints on further research on the general influence of corporate boards. Previous literature on corporate governance characteristics has investigated performance, value, but only few studies analysed tax planning using tax savings and booktax difference. There is an obvious gap in literature to fill. For practitioners, the study illustrates that governance controls are significant issue on tax planning. Hence, expanding boards' monitoring may moderate the risk of rent diversions and providing the incentives for boards of directors to be more disposed to tax planning risk.

\section{REFERENCES}

Abdul Wahab, N. S. (2010). Tax planning and corporate governance: Effects on shareholders valuation. Thesis for the degree of Doctor of Philosophy, University of Southampton, Southampton UK. http://eprints.soton.ac.uk/162801/.

Abdul Wahab, N. S., \& Holland, K. (2012). Tax planning, corporate governance and equity value. The British Accounting Review, 44, 111-124. http://dx.doi.org/10.1016/j.bar.2012.03.005.

Abdul Wahab, N. S., \& Holland, K. (2015). The persistence of book-tax differences. The British Accounting Review, 47, 339-350. http://dx.doi.org/10.1016/j.bar.2014.06.002.

Abdul Wahab, N. S., Holland, K., \& Soobaroyen, T. (2015). Do UK outside CEOs engage more in tax planning than the insiders? Jurnal Pengurusan, 45, 119-129.

Abdul Wahab, N.S. (2016). Malaysian multinational companies (MNC): Permanent and temporary nature of tax planning. Cogent Business \& Management, 3: 1248644. http:/dx.doi.org/10.1080/23311975.2016.1248644

Aburajah, L., Maali, B., Jaradat, M. \& Alsharairi, M. (2019). Board of directors' characteristics and tax aggressiveness: Evidence from Jordanian listed firms. Theoretical Economics Letters, 9, 2732-2745.

Adegboyegun, A.E., Alade, M.E., Ben-Caleb, E., Ademola, A.O., Eluyela, D.F. \& Oladipo, O.A. (2020), Integrated reporting and corporate performance in Nigeria: Evidence from the banking industry, Cogent Business \& Management, 7:1, 1736866.

Adeleke, E.O., Adeyanyu, O.D. \& Akinselure, O.P. (2018). Impact of accounting theory on financial reporting in Nigeria, International Journal of Economics, Commerce \& Management, VI(4), 193 - 206.

Ahiauzu, A.I. \& Asawo, S.P. (2016). Advanced Social Research Methods, CIMRAT Publications. 
Ahmadi, A., Nakaa, N., \& Bouri, A. (2018). Chief Executive Officer attributes, board structures, gender diversity and firm performance among French CAC 40 listed firms. Research in International Business and Finance, 44, 218-226.

AICPA. (2015). Introduction to personal income tax planning. http://www.aicpa.org/interestareas/personalfinancialplanning/cpeandevents/pages/taxvents.aspx

Akewuosha, R.O. and Saka, R.O. (2018). Executive compensation and organisational financial performance: Evidence from selected diversified firms in Nigeria. IOSR Journal of Business and Management, 20(3), 8 - 17.

Akintoye, I.R., Adegbie, F.F. \& Iheme-Onyeka, C.V. (2020). Tax planning strategies and profitability of quoted manufacturing companies in Nigeria. Journal of Finance and Accounting, 8(3), 148-157.

Ali-Jabali, M. A. (2013). Framing accounting theory theoretical and practical, European Journal of Economics, Finance \& Administrative Sciences, 57, 145 - 149.

Ali-Jabali, M. A. (2013). Framing accounting theory theoretical and practical, European Journal of Economics, Finance \& Administrative Sciences, 57, 145 - 149.

Alstadsaeter, A. \& Jacob, M. (2013). Who participates in tax avoidance? Working paper. University of Oslo and WHU - Otto Beisheim School of Management.

Andrew, B. \& Stephen, A.K. (2015). Governance and taxes: Evidence from regression discontinuity. Tepper School of Business, Carnegie Mellon University, USA. https://meridian.allenpress.com/accounting-review/article-abstract/92/1/29/99335

Appah, E. (2020). Research Methodology: Principles, Methods and Techniques, Vinson Printing and Publishing Enterprises.

Appolos, N., Kwarbai, J., \& Ogundajo, G. (2016). Tax planning and firm value: empirical evidence from Nigerian consumer goods industrial sector. Research Journal of Finance and Accounting, 7(12), 2222-2847.

Armstrong, C. S., Blouin, J. L., \& Larcker, D. F. (2012). The incentives for tax planning. Journal of Accounting and Economics, 53(1), 391-411.

Armstrong, C. S., Blouin, J. L., Jagolizner, A. D. \&Larcker, D. F. (2015). Corporate governance, incentives and tax avoidance, Journal of Accounting and Economics, 60, 117.

Asterious, D. \& Hall, S. (2007). Applied Econometrics: A Modern Approach. Palgrave Macmillan.

Auerbach, A. J., Devereux, M. P., Keen, M., \& Vella, J. (2017). International tax planning under the destination-based cash flow tax. National Tax Journal, 70(4), 783-802. https://doi.org/10.17310/ntj.2017.4.04

Ayers, B. C., Call, A. C., \& Schwab, C. M. (2018). Do analysts' cash flow forecasts encourage managers to improve the firm's cash flows? Evidence from tax planning. Contemporary Accounting Research, 35(2), 767-793. https://doi.org/10.1111/19113846.12403

Ba'aba, S. \& Bashiru, M. (2019). The impact of corporate governance attributes on tax planning of listed manufacturing companies: A comparative study between Nigeria and Malaysia. Review of Politics and Public Policy in Emerging Economies, 1(2), 105-112.

Badertscher, B.A, Katz, S.P. \& Rego, S.O. (2013). The separation of ownership and control and corporate tax avoidance. Journal of Accounting and Economics, 56, 228-250.

Baridam, D.M. (2008). Research methods in administrative sciences. Sherbrooke Associates.

Barro, V. \& Samento, J.M. (2020). Board meeting attendance and corporate tax avoidance: Evidence from the UK. Business Perspectives and Research, 8(1), 51-66. 
Bashiru, M., Ba'aba, S. \& Bukar, M. (2020). The impact of corporate governance attributes on tax planning of listed Nigerian conglomerate companies. International Journal of Academic Research in Business and Social Sciences, 10(5), 229-238.

Bashiru, M., Ba'ba, S., \& Bukar, M. (2020). The impact of corporate governance attributes on tax planning of listed Nigerian conglomerate companies. International Journal of Academics Research in Business and Social Sciences, 10(5), 229-238.

Beryl, A. O. (2014). The relationship between ownership structure and tax avoidance of companies listed at the Nairobi Securities Exchange, (Unpublished MSC Thesis), University of Nairobi, Kenya.

Binh, D.T.T. \& Anh, T.T.K. (2017). Stakeholders approach on corporate governance and performance of Vietnamese manufacturing firms, Journal of Governance and Regulation, 6(2), 61 - 72.

Blattberg, C. (2004). From Pluralist to Patriotic Politics: Putting Practice First. Oxford University Press.

Bond, S., Gammie, M., \& Whiting, J. (2012). Tax avoidance. The IFS Green Budget January 2012. http://www.ifs.org.uk/budgets/gb2012/gb2012.pdf

Cabeza-García, L., Fernández-Gago, R., \& Nieto, M. (2018). Do board gender diversity and director typology impact CSR reporting? European Management Review, 5, 559-575.

Chabachib, M., Fitriana, T. U., Hersugondo, H., Pamungkas, I. D., \& Udin, U. (2020). Firm value improvement strategy, corporate social responsibility, and institutional ownership. International Journal of Economics and Management Systems, 10(4), 152-163.

Chen, C. \& Lai, S. (2012). Financial constraints and tax avoidance. Working Paper, University of Auckland and the Chinese University of Hong Kong.

Chen, S., Chen, X., Cheng, Q. \& Shevlin, T. (2010). Are family firms more tax aggressive than non-family firms. Journal of Financial Economics, 95(1), 41-61.

Christina, S. \& Alexander, N. (2018). Corporate governance, tax planning and firm value. $7^{\text {th }}$ International Conference on Entrepreneurship and Business Management, (ICEBM), 233-237.

Christina, S. (2019). The effects of tax planning on firm value. Accounting and Finance Review, 4(1), 01-04.

Chukwudi, U.V., Okonkwo, O.T. \& Asika, E.R. (2020). Effect of tax planning on firm value of quoted consumer good manufacturing firms in Nigeria. International Journal of Finance and Banking Research, 6(1), 1-10.

Chytis, E., Tasios, S., \& Gerantonis, N. (2018). Tax avoidance and corporate governance attributes: Evidence from listed companies in Greece. 15th International Conference on Enterprise, Systems, Accounting, Logistics and Management (15 ICESALM), 24 - 26 June, Kefalonia, Greece.

Chytis, E., Tasios, S., Georgopoulos, I. \& Hortis, Z. (2019). The relationship between tax avoidance, company characteristics and corporate governance: evidence from Greece. Corporate Governance and Control, 16(4), 77 - 86.

Cordeiro, J., He, L., Conyon, M., \& Shaw, T. (2016). Chinese executive compensation: The role of asymmetric performance benchmarks. The European Journal of Finance, 22(46), 484-505.

Dallas, L. (2011). Short-termism, the financial crisis, and corporate governance. Social Science Electronic Publishing, 266-361.

Dariuni, N.H., Zohdi, A.R. \& Jamdi, A.H. (2019). Corporate governance and relationship between ownership structure, social responsibility and tax avoidance. International Journal of Business Management, 4(1), 126-141. 
Deef, A.T., Alrawashdeh, B. \& Al-Fawaerh, N. (2021). The impact of foreign ownership and managerial ownership on tax avoidance: Empirical evidence from Egypt. Academy of Accounting and Financial Studies Journal, 25(2), 1-13.

DeFond, M.L., \& Lennox, C.S., (2011). The effect of SOX on small auditor exits and audit quality. Journal of Accounting and Economics, 52, 21-40.

Desai, M. A. \& Dharmapala, D. (2006). Corporate tax avoidance and high powered incentives. Journal of Financial Economics, 79, 145-179.

Dharmapala, D., \& Riedel, N. (2012). Earnings shocks and tax-motivated income-shifting: Evidence from European multinationals. Journal of Public Economics, 97(11-12), 95107.

Ding, D., Duan, T., Hou, W., \& Zhang, J. (2013). The burden of attention: The impact of CEO publicity on tax avoidance. Working paper. Southampton University Management School, Highfield Campus and University of Edinburgh Business School. Electronic copy available at, $\mathrm{http}, / / \mathrm{ssrn}$.com/abstract $=2426413$.

Dridi, W. \& Boubaker, A (2016). Corporate governance and book-tax differences: Tunisian evidence. International Journal of Economics and Finance, 8(1),171-186.

Dyreng, S., Hanlon, M, \& Maydew, E.L. (2008). Long-run corporate tax avoidance. The Accounting Review, 83, 61-82.

Edwards, A., Schwab, C. \&Shevlin, T. (2013). Financial Constraints and the Incentives for Tax Planning. Working paper. Universities of Toronto, Georgia and California at Irvine.

Eriabie, S.O. and Izedonmi, (2016). Impact of audit committee attributes on financial reporting quality in Nigerian quoted companies. ICAN Journal of Accounting and Finance 5(1): 117-137.

Evangelos C., Stergios, T., \& Ioannis, F. (2020). The effect of corporate governance mechanisms on tax planning during financial crisis: an empirical study of companies listed on the Athens stock exchange. International Journal of Disclosure and Governance, 17(1), 30-38.

Ezejiofor, R.A. \& Ezenwafor, E.C. (2020). Corporate governance and tax avoidance: Evidence from Nigerian quoted food and beverage companies. Macro Management \& Public Politics, 2(4), 40-47. DOI:http://doi.org/10.30564/mmpp.v2i4.2632

Fagbemi, T.O., Olaniyi, T.A. \& Ogundipe, A.A. (2019). The corporate tax planning and financial performance of systemically important banks in Nigeria. Ekonomaki Horizonti, 21(1), 15-28.

Fernandez-Rodriguez, E., García-Fernández, R., \& Martínez-Arias, A. (2019). Influence of ownership structure on the determinants of effective tax rates of Spanish companies. Sustainability, 11(5), 1441.

Freeman, R.E., Harrison, J.,Wicks, A., Parmar, B., \& de Colle, S. (2010). Stakeholder theory: The state of the art. Cambridge University Press.

Gaertner, F.B. (2014). CEO after-tax compensation incentives and corporate tax avoidance. Contemporary Accounting Research, 31(4): 1077-1102.

Gravetter, F.J. \& Forzano, L-A. B. (2019). Research methods for the behavioural sciences. Wadsworth-Cengage Learning.

Gujarati, D.N. \& Porter, D.C. (2009). Basic Econometrics (5 ${ }^{\text {th }}$ ed). McGraw Hill.

Halioui K., Neifar S. \& Abdelaziz F.B. (2016). Corporate governance, CEO compensation and tax aggressiveness: Evidence from American firms listed on NASDAQ 100. Review of Accounting and Finance, 15(4), pp. $445-462$.

Hanlon, M., \& Heitzman, S. (2010). A review of tax research. Journal of Accounting and Economics, 50(2), 127-178. 
Hasibuan, D. \& Khomsiyah, O. (2019). Do corporate governance affect tax aggressiveness? Evidence from Indonesia. Journal of Accounting, Business and Financial Research, $7(1), 8-16$.

Hoseini, M. \& Gerayli, M.S. (2018). The presence of women on the board and tax avoidance: Evidence from Tehran Stock Exchange. International Journal of Finance and Managerial Accounting, 3(9), 53-62.

Howell O'Neill, J. (2012). Innovation and constraints on tax shelters. Faulkner Law Review, $4(1), 1-35$.

Huang, D. F., \& Wang, C. L. (2013). Book-tax differences and earnings quality for the banking industry: evidence from Taiwan, Pacific Accounting Review, 25 (2), 145-164.

Hulya, C. (2016). Corporate governance and firm profitability. International Journal of Trade, Economics and Finance, 7(1), 24-30.

Igbinovia, I.M. \& Ekwueme, C.M. (2018). Corporate tax avoidance and shareholder return: moderating effects of monitoring. Sriwijaya International Journal of Dynamic Economics and Business, 2(3), 255-268.

Ilaboya, O. J., Izevbekhai, M. O. \& Ohiokha, F. I. (2016). Tax planning and firm value: A review of literature. Business and Management Research, 5 (2), 81-91. Doi: 10.5430/bmr.v5n2p81. http://bmr.sciedupress.com.

Imuetinuan, I.B., Soomon, E.A. C. \& Jonathan, A. (2019). Effects of board characteristics, firm performance and tax planning in Nigeria food manufacturing sector. FUO Quarterly Journal of Contemporary Research, 7(3), 1-12.

Inua, O.I. (2018). Determinants of corporate effective tax rate: Empirical evidence from listed manufacturing companies in Nigeria. Accounting and Taxation Review, 2(3), 48-62.

Iqbal N. \& Khan, N. (2015). Evolution of corporate governance practices and conventional banks profitability. Journal of Business and Financial Affairs, 4(2), 1-4.

Irawan, H. P., \& Farahmita, A. (2013). Effects of management compensation and corporate governance on corporate tax management. Paper presented at the National Symposium on Accounting XVI Manado. Indonesian Accounting Association Compartment Educator Accountants.

Izevbekhai, M.O. \& Odion, A.O. (2018). Tax planning and firm value. Nigerian Academy of Management Journal, 13(1), 94-119.

Jaewoo, K., Philip, Q. \& Ryan, W. (2016). Managerial ownership and tax planning: Evidence from stock ownership plans. Workshop at the University of Arkansas. https://studylib.net/doc/14641442/managerial-ownership-and-tax-planning--evidencefrom-stock

Jamei, R. (2017). Tax avoidance and corporate governance mechanisms: Evidence from Tehran Stock Exchange. International Journal of Economics and Financial Issues, 7(4), 638-644.

Kaczmarek, S., Kimino, S., \& Pye, A. (2014). Interlocking directorships and firm performance in highly regulated sectors: the moderating impact of board diversity. Journal of Management \& Governance, 18(2), 347-372. https:// doi.org/10.1007/s10997-012-9228-3.

Kadir, O.A. (2018). The impact of corporate governance mechanisms on corporate tax avoidance in Nigeria listed manufacturing companies. Global Journal of Contemporary Research, Auditing and Business Ethics, 4(9), 622 - 636.

Khan, S.N., Ismail, E. \& Ali, E. (2017). How intellectual capital moderates the relationship between corporate governance and firm performance in the capital market of Pakistan: 
A conceptual review and Proposal. International Journal of Economic Perspectives, 11(2), 359-71.

Kiabel, B. D., \& Akenbor, C. O. (2014). Tax planning and corporate governance in Nigerian banks. European Journal of Business and Management, 6(19), 235-243.

Kothari, C.R. (2012). Research Methodology: Methods and Techniques, (2nd ed), New Age International Publishers.

Kpolovie, P.J. (2010). Advanced Research Methods. Springfield Publishers.

Lanis, R., \& Richardson, G. (2012). Corporate social responsibility and tax aggressiveness : An empirical analysis. Journal of Accounting and Public Policy, 31(1), 86-108.

Lanis, R., Richardson, G. \& Taylor, G. (2017). Board of director gender and corporate tax aggressiveness: An empirical analysis. Journal of Business Ethics, 144, 577-596.

Lee, B. B., Dobiyanski, A. \& Minton, S. (2015). Theories and Empirical Proxies for Corporate Tax Avoidance, Journal of Applied Business and Economics 17(3), 21-35.

Lestari, N. \& Wardhani, R. (2015). The effect of the tax planning on firm value with moderating board diversity. International Journal of Economics and Financial Issues, 5, 515-323.

Lisowsky, P., Robinson, L., \& Schmidt, A. (2013). Do public disclosed reserves tell us about privately disclosed tax shelter activity? Journal of Accounting Research, 51(3), 583629.

Madawaki, A. \& Amran, N.A. (2013). Audit committee: How they affect financial reporting in Nigerian companies, Journal of Modern Accounting and Auditing, 9(8), 1070 - 1080.

Mais, R.G. \& Patminigih, D. (2017). Effect of corporate governance on tax avoidance of the company listed on the Indonesia Stock Exchange. Jurnal STEI Ekonomi, 26(2), 230 243.

Mansell, S. (2013) Capitalism, Corporations and the Social Contract: A Critique of Stakeholder Theory. Cambridge University Press, https://doi.org/10.1017/CBO9781139058926

McClure, R. \& Lanis, R. (2015). Corporate tax avoidance and minimisation. http://economics.sen@aph.gov.au.

McGuire S.T., Thomas C.O., \& Wang D. (2012). Tax Avoidance: Does Tax-Specific Industry Expertise Make a Difference? The Accounting Review, 87(3), 975-1003.

Mgammel, M.H. \& Ismail, K.N.I.K. (2015). Corporate tax planning activities: Overview of concepts, theories, restrictions, motivations, and approach. Mediterranean Journal of Social Sciences, 6(6), 350-358.

Mgammel, M.H. (2015). The effect of tax planning and corporate governance on tax disclosure of Utaria Malaysia.

Mgammel, M.H. (2017). Corporate tax planning and corporate tax disclosure, Meditari Accountancy Research, 28(2), 327 - 364. https:doi.org/10.1108/MEDAR-11-20180390.

Mohammad, A.N. (2017). Effects of corporate governance mechanism on tax avoidance in deposit money banks in Nigeria. Unpublished PhD Thesis, Ahmadu Bello University, Zaria, Nigeria.

Mozaffar, K., Srinivasan, S. \& Tan, L (2017). Institutional ownership and corporate tax avoidance: New evidence. The Accounting Review, 92(2), 101-122.

Murni, Y., Sudarmaji, E. \& Sugihyahi, E. (2016). The role of institutional ownership, board of independent commissioner and leverage: corporate tax avoidance in Indonesia. IOSR Journal of Business and Management, 18(11), 79-85. 
Mustika, M., Sulistyowati, S. \& Wahyuni, E.N. (2019). Examining the impact of liquidity, leverage \& earning management on corporate tax aggressiveness in property and real estate companies in Indonesia Stock Exchange. Advances in Economics, Business and Management Research, 127, 97-100.

Nadeem, M., Zaman, R. \& Saleem, I. (2017). Boardroom gender diversity and corporate sustainability practices: Evidence from Australian Securities Exchange listed firms. Journal of Cleaner Production, 149, 874-885.

Narbel, F. \& Muff, K. (2017). Should the evolution of stakeholder theory be discontinued given its limitation? Theoretical Economics, 7, 1357 - 1381.

Ndiyo, N.A. (2015), Fundamentals of Research in Behavioural Sciences and Humanities. Wusen Publishers.

Nengzih, E. (2018). Determinants of corporate tax avoidance: Survey on Indonesia's public listed Company. International Journal of Economics, Business and Management Research 2(2), 133-145.

Nomura, H. (2017). What determines Japanese effective tax rates? Evidence from firms listed on the Tokyo Stock Exchange. KEA - APEA 2017 conference, Seoul, 1-18.

Novita, E.S. \& Heritiansyah, Y. (2019). The effect of corporate governance mechanism, liquidity, and corporate size on tax avoidance. Saudi Journal of Economics and Finance, 3(9), 366-373.

Nwaobia, A., Kwarbai, J., \& Ogundajo, G. (2016). Tax Planning and Firm Value: Empirical evidence from Nigerian consumer goods industrial sector. Research Journal of Finance and Accounting, 7(12), 172-183.

Nwezoku, N.C. \& Egbunike, P.A. (2020). Board diversity and corporate tax aggressiveness behaviour of quoted healthcare manufacturing firms in Nigeria. International Journal of Advanced Academic Research, 6(2), 66-95.

OECD (2013). Addressing base erosion and profit shifting. Paris: OECD.

Oeta, S.M., Kiai, R. \& Muchiri, J. (2019). Influence of tax planning on financial performance of manufacturing companies listed at Nairobi Securities Exchange. International Journal of Research in Business and Social Sciences, 8(6), 262-269.

Ogbeide, S., \& Akanji, B. (2016). Executive remuneration and the financial performance of quoted firms: The Nigerian experience. Management and Economics Review, 1(2), 229242.

Ogbeide, S.O. \& Obaretin, O. (2018). Corporate governance mechanisms and tax aggressiveness of listed firms in Nigeria. Amity Journal of Corporate Governance, 3(1), $1-12$.

Ogundajo, G. O., \& Onakoya, A. B. (2016). Tax planning and financial performance of Nigerian manufacturing companies. International Journal of Advanced Academic Research Social \& Management Sciences, 2(7), 64-80.

Olalekan, O.C. \& Bodunde, O.O. (2015). Effect of CEO pay on bank performance in Nigeria: Evidence from a generalized method of moments. British Journal of Economics, Management and Trade, 9(2), 1-2.

Olaniyi, C.O., Obembe, O.B. \& Oni, E.O. (2017). Analysis of the nexus between CEO pay and performance of non-financial listed firms in Nigeria. African Development Review, 29(3), 429-445.

Omesi, I. \& Appah, E. (2020). Tax structure and economic growth in Nigeria: An auto regressive distributive lag evidence from 1980 to 2018. International Journal of Innovations in Marketing and Accounting Research, 8(1), 108-124. 
Omesi, I. \& Appah, E. (2021). Corporate governance and tax avoidance of listed consumer and industrial goods companies in Nigeria. IOSR Journal of Economics and Finance, 12(2), 17 - 31. doi:10.9790/5933-1202041731

Omoregie, O.K. \& Kelikume, I. (2017), Executive compensation and banking sector performance: Evidence from Nigeria. The Journal of Developing Areas, 51(2), 1-15.

Onyema, L.I. \& Major, H.I. (2021). Corporate governance mechanism and audit quality of listed deposit money banks in Nigeria. Journal of Accounting Research, 7(4), 75 - 88.

Pattiasina, V., Tammubua, M.H., Numberi, A., Patiran, A. \& Temalagi, S. (2019). Capital intensity and tax avoidance: A case of Indonesia. International Journal of Social Sciences and Humanities, 3(1), 58 - 71. http://doi.org/10.29332/ijssh.v3ni.250

Păunescu, R. A., Vintilă, G., \& Gherghina, Ş. C. (2016). Exploring the link between corporate governance characteristics and effective corporate tax rate: A panel data approach on U.S. listed companies. Journal of Financial Studies and Research, (October), 1-16. https://doi.org/10.5171/2016.857506

Peter, Z., Hamid, T.K. \& Ibrahim, M. (2020). Board attributes and tax planning of listed nonfinancial companies in Nigeria. International Journal of Accounting and Finance, 9(1), $130-146$.

Pfeffer, J. (1973). Size, composition and function of corporate boards of directors: The organization environment linkages. Administrative Science Quarterly, 18, 349-364.

Philips, R., Freeman, R.E. \& Wicks, A.C. (2003). What stakeholder theory is not? Business Ethics Quarterly, 13(4), 479-502.

Pratama, A. (2017). Company characteristics, corporate governance and aggressive tax avoidance practice: A Study of Indonesian companies. Review of Integrative Business and Economics Research, 6(4), 70-81.

Putri, G.N., Setiawan, V., Faisol, A., Roza, F. \& Yulda, F.P. (2018). Does corporate governance affect tax planning? A case study of a manufacturing company. Research Journal of Finance and Accounting, 9(16), 95-101.

Rappaport, A. (2005). The economics of short-term performance obsession. Financial Analysts Journal, 61, 65-79. https://doi.org/10.2469/faj.v61.n3.2729

Razali, M.W.M., Ghazali, S.S., Lunyai, J. \& Hwang, J.Y.T. (2018). Tax planning and firm value: Evidence from Malaysia. International Journal of Academic Research in Business and Social Sciences, 8 (11), 210-222.

Razali, M.W.M., Razak, A.E.A., Sheuna, S.C.C., \& Ali, D.H.A. (2019). Directors remuneration and tax planning of listed companies, International Journal of Asian Social Sciences, 9(11), 544 -555.

Rego, \& Wilson, R. (2012). Executive compensation, equity risk incentives and corporate tax aggressiveness. Journal of Accounting Research, 50(3), 775-810.

Reguera-Alvarado, N., de Fuentes, P.; \& La-arga, J. (2017). Does board gender diversity influence financial performance? Evidence from Spain. Journal of Business Ethics, 141, 337-350.

Ribeiro A., Cerqueira A. \& Brandao E. (2015). The determinants of effective tax rates: Firms' characteristics and corporate governance. FEP Working Papers, University of Porto.

Sabli, N., \& Noor, R. M. (2012). Tax planning and corporate governance. Paper presented at the International Conference on Business and Economic, 12-13 March Golden Flower Hotel, Bandung, Indonesia. www.Internationalconference.Com.My. 
Salawu R.O. \& Adedeji, Z.A. (2017). Corporate governance and tax planning among nonfinancial quoted companies in Nigeria. African Research Review: An International Multi-Disciplinary Journal, 11(3), 42-59.

Saona, P., Muro, L., \& Alvarado, M. (2020). How do the ownership structure and board of directors' features impact earnings management? The Spanish case. Journal of International Financial Management \& Accounting, 31(1), 98-133. https://doi.org/10.1111/jifm.12114

Sartaji, A. \& Hassanzadeh, A. (2015). Investigating the relationship between corporate governance and tax violations in Tehran Stock Exchange. International Journal of Accounting Research, 1(12), 77-85.

Seyram K. \& Holy, K. K. (2014). Effect of tax planning on firms market performance: evidence from listed firms in Ghana. International Journal of Economics and Finance 6(3), 23-39.

Soufiene A., Khoula A., \& Mohamed A. O. (2016). Tax optimization and the firm's value: Evidence from the Tunisian context, Borsa Istanbul Review, 16 (3), 177-184.

Sunarto, S., Widjaja, B. \& Oktaviani, R.M. (2021). The effect of corporate governance on tax avoidance: The role of profitability as a mediating variable. Journal of Asian Finance, Economics and Business, 8(3), 0217 - 0227.

Sundaram, A. \& Inkpen, A. (2004). The corporate objective revisited. Organizational Science, 15, 350-363. https://doi.org/10.1287/orsc.1040.0068

Sunday, U., Nosa, O., \& Imuetinyan, E. (2019). Corporate Determinants of Aggressive Tax Avoidance: Evidence from Nigeria, Journal of Business and Management, 21(4), 1-9.

Tanko, U.M. (2020). The moderating effect of profitability on the relationship between ownership structure and corporate tax avoidance in Nigeria listed consumer goods firms. Journal of Material and Manufacturing Research, 1(1), 1-16.

Taylor, G. \& Richardson, G. (2013). The determinants of thinly capitalized tax avoidance structures: Evidence from Australian firms. Journal of International Accounting, Auditing and Taxation 22, 12-25.

Tijjani, B. \& Peter, Z. (2020). Ownership structure and tax planning of listed firms: Evidence from Nigeria. Journal of Accounting and Taxation, 12(3), 99-107.

Timothy, O.U., Izilin, M.O. \& Ndifereke, B.A. (2020). Corporate tax planning, board compensation and firm value. Accounting and Taxation Review, 4(3), 11-28.

Uchendu, O., Ironkwe, U.I \& Nwaiwu, J.N. (2016). Corporate governance mechanism and tax planning in Nigeria. International Journal of Advanced Academic Research (Social and Management Sciences), 2(9), 45-59.

Uniamikogbo, E., Benee, E. \& Adeusi, S.A. (2019). Corporate governance and tax aggressiveness in Nigeria. AE-FUNAI Journal of Accounting, Business and Finance, 4(1), 20-33.

Vacca, A., Iazzi, A., Vrontis, D. \& Fait, M. (2020). The role of gender diversity on tax aggressiveness and corporate social responsibility: Evidence from Italian listed companies. Sustainability, 12, 1-14.

Vu, T.A.T \& Le, V.H. (2021). The effect of tax planning on firm value: A case of study in Vietnam. Journal of Asian Finance, Economics and Business, 8(2), 0973-0979.

Waluyo (2017). The effect of good corporate governance on tax avoidance: empirical study of the Indonesian banking sector. The Accounting Journal of Binaniasa, 2(2), 1-10.

Worlu, C.N. (2018). Accounting Ethics, Social Responsibility and Corporate Governance. Glory of the Latter House Publishing Company. 
Yetty, M., Eka, S. \& Eneng S (2016). The role of institutional ownerships, board of independent commissioner and leverage: Corporate tax avoidance in Indonesia. Journal of Business and Management, 18(11), 79-85.

Yimbila, B. (2017). Tax planning, corporate governance and performance of banks in Ghana. A Master Thesis, University of Cape Coast.

Ying, T. (2016). Corporate governance and tax strategies in Chinese listed firms. Unpublished $\mathrm{PhD}$ Thesis, University of Nottingham. http://eprints.nottingham.ac.uk/28838/1/PhD\%20submision_Tingting\%20Ying

Yu, P., \& Van-Luu, B. (2016). Bank performance and executive pay: Tournament or teamwork. Review of Quantitative Finance and Accounting, 47(3), 607-643.

Yuniarsih, N. (2018). The effect of accounting conservatism and corporate governance mechanism on tax avoidance. Academic Research International, 9(3), 68 - 76.

Zemzem, A., \& Ftouhi, K., (2013). External Corporate Governance, Tax Planning, and Firm Performance. Corporate Ownership \& Control, 13(3), 23-38.

Zemzem, A., \& Ftouhi, K., (2013). The effects of board of directors' characteristics on tax aggressiveness. Journal of Finance and Accounting, 4 (4), 14 - 28.

Zhu, N., Mbroh, N., Monney, A. \& Bonsu, M.O.A. (2019). Corporate tax avoidance and firm performance. European Scientific Research, 15(7), 61- 70. 